\title{
Narrativas do Axé
}

\section{A Umbanda e suas múltiplas Linguagens}
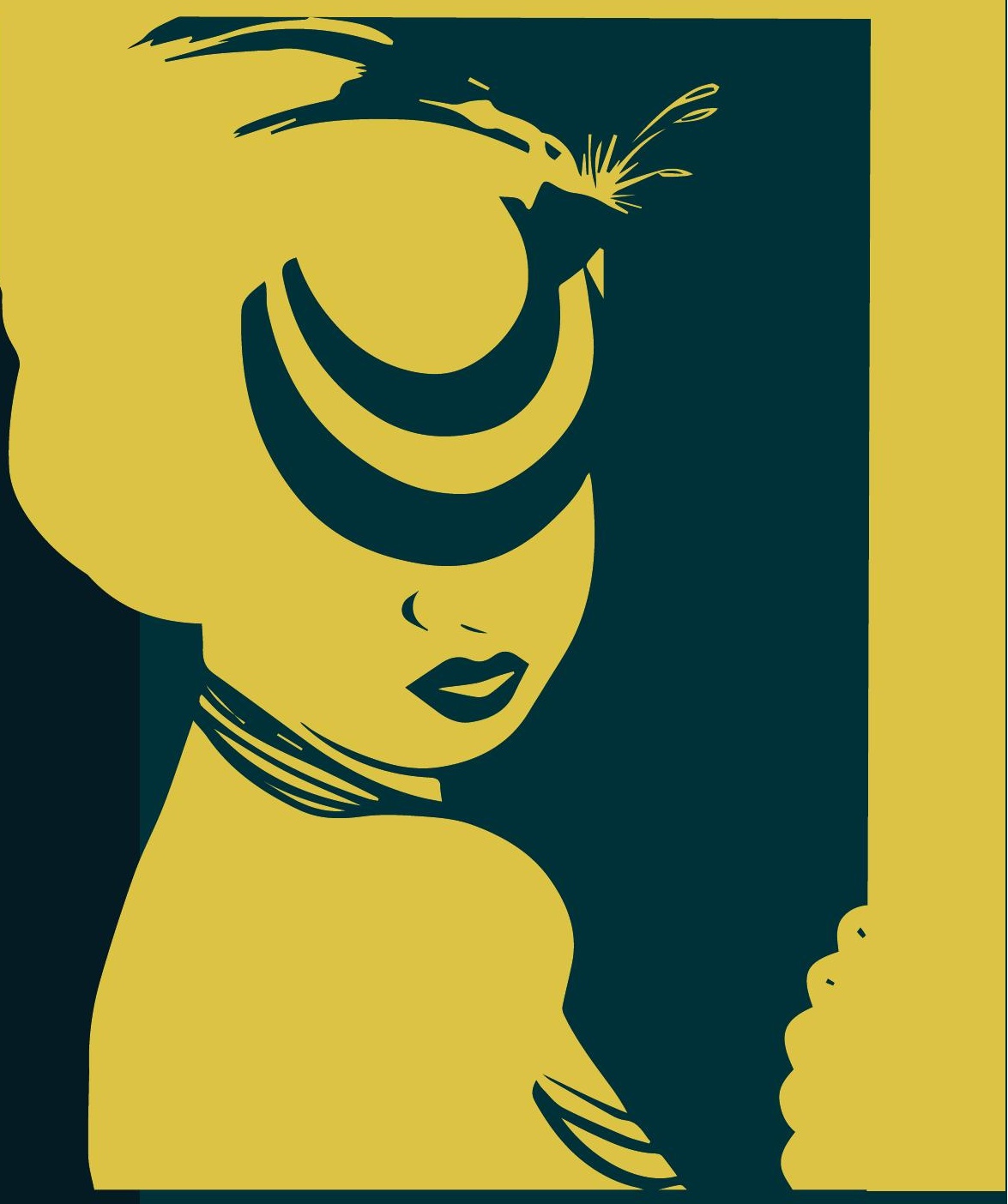

Cairo Mohamad Ibrahim Katrib

Tadeu Pereira dos Santos Rodiney Nunes de Oliveira 
NARRATIVAS DO AXÉ 


\section{Editora Culturatrix.}

| publicações acadêmicas |

Editora chefe

Rosa Maria Ferreira da Silva
Editor assistente

Cairo Mohamad Ibrahim Katrib (UFU)

\section{Conselho Editorial}

Eliane Martins de Freitas (UFG - Catalão)

Emília Saraiva Nery (FACEMA)

Euclides Antunes de Medeiros (UFT)

Floriana Rosa da Silva (SRE-MG)

lara Toscano Correia (UFU)

Helena Maria Ferreira (UFLA)

Luís André Nepomuceno (UNIPAM)

Marcos Antônio de Menezes (UFG)

Maria Clara Tomaz Machado (UFU)

Miguel Rodrigues de Sousa Neto (UFMS)

Olívia Cormineiro (UFT)

Regma Maria dos Santos (UFG - Catalão)

Remi Castioni (UnB)

Renato Jales Silva Júnior (UFMS)

Ricardo Vidal Golovaty (IFG)

Simone Aparecida dos Passos (UFU)

Tadeu Pereira dos Santos (UNIR)

culturatrix. 


\section{NARRATIVAS DO AXÉ}

- A Umbanda e suas múltiplas linguagens -

Cairo Mohamad Ibrahim Katrib

Tadeu Pereira dos Santos

Rodiney Nunes de Oliveira 
Copyright 2020 @ Cairo Mohamad Ibrahim Katrib, Tadeu Pereira dos Santos, Rodiney Nunes de Oliveira 2020.

Todos os direitos reservados.

* O conteúdo desta obra, bem como sua originalidade, revisão gramatical e ortográfica são de inteira responsabilidade dos autores.

Editora de Publicação: Rosa Maria Ferreira da Silva

Projeto Gráfico e capa: Igor Ferreira

Diagramação: Stúdio Escrita \& Criação

Dados Internacionais de Catalogação na Publicação (CIP)

Nelson Marcos Ferreira - CRB-6 / 3074

K19n Katrib, Cairo Mohamad Ibrahim, 1971-

Narrativas do axé : a Umbanda e suas múltiplas linguagens / Cairo Mohamad Ibrahim Katrib, Tadeu Pereira dos Santos, Rodiney Nunes de Oliveira. -- Uberlândia : Culturatrix, 2020.

100 p. : il.

ISBN: 978-65-86889-03-1 (e-book)

DOI: 10.4322/978-65-86889-03-1

Formato: Digital

Extensão: PDF

Inclui bibliografia.

1. Umbanda. 2. Religiosidade. 3. História cultural. 4. Cultura popular. 5. Memórias. 6. Mulheres. I. Katrib, Cairo Mohamad Ibrahim, 1971-. II. Santos, Tadeu Pereira dos, 1978-. III. ); Oliveira, Rodiney Nunes de, 1969-.

CDU:

299.6

Rua Nordau Gonçalves de Mello, 1116, Santa Mônica.

CEP: 38408 218. Uberlândia, MG. Tel. (34) 3477 0860/

Cel./WatsApp: (34) 997668930

CNPJ: 26896 970/0001-00

www.culturatrix.com - contato.culturatrix@gmail.com 


\section{SUMÁRIO}

INTRODUÇÃO 6

Saberes, fazeres e práticas na Umbanda:

Refletindo sobre a pedagogia do sagrado

CAPÍTULO 1

Heranças da memória, histórias em

Reconstrução

CAPÍTULO 2

O fazer-se sujeito/mulher de

Dona Maria Isabel da Silva

CAPÍTULO 3

Da religiosidade popular às matrizes africanas: a Umbanda como lugar de fala

CONSIDERAÇÕES FINAIS

REFERÊNCIAS 
INTRODUÇÃo

\title{
Saberes, fazeres e práticas na Umbanda: Refletindo sobre a pedagogia do sagrado
}

\author{
[...] que a importância de uma coisa não se mede com fita métrica \\ nem com balanças nem barômetros etc. Que a importância de uma coisa há que \\ ser medida pelo encantamento que a coisa produza em nós.
}

(Manoel de Barros, 2006)

Este livro é fruto de inquietações, surgidas de conversas e trocas de experiências entre historiadores. É reflexo das últimas pesquisas realizadas por nós, os autores, acerca da cultura e da religiosidade afro-brasileiras, tomando este campo investigativo não numa perspectiva dura e linear, mas como seara de possibilidades para se pensar o outro, suas práticas, seus saberes.

Da mesma forma, a temática aqui abordada funciona como gatilho para a compreensão de uma realidade que, embora distante geograficamente, apresenta elementos comuns. Através de suas similitudes, esta realidade referenda os modos de ser e agir de sujeitos singulares que reconstroem histórias e fincam memórias fora das glebas do esquecimento. 
Neste processo, nos revelam suas dores, suas mágoas, seus desejos, desvelando alguns dos inúmeros segredos no "existir".

Apresentamos aqui uma análise breve, mas que se pretende rica de sentidos e significados, exemplificados pelo fazer cotidiano de mulheres, negras, detentoras do saber, do Axé e que, a despeito de não se conheceram, fazem/fizeram da Umbanda sinônimo de vida, no exercício religioso afro-brasileiro. Umas em Minas Gerais, no Triângulo Mineiro; outra em Rondônia. Cada uma, do seu modo, conectando-se ao campo espiritual por meio de uma pedagogia desenvolvida no chão do Terreiro, fruto de suas vivências e intuições.

Neste livro, procuramos explicitar fragmentos, impressões do processo de "fazer-se", registradas pelo olhar do pesquisador que vai in loco, observa, se movimenta e se projeta no lugar do outro. Na oscilação deste pêndulo antropológico, procura entender o outro na sua pluralidade. E, assim, experimenta sensações e busca externar com palavras sentimentos, cheiros, calor, vibrações. Através do processo de verbalização da memória herdada, torna possível emergir histórias vividas, silenciadas e até então adormecidas, permitindo-nos enveredar pelo encantado e sinuoso universo religioso afro-brasileiro.

Não obstante, antes de apresentarmos estas mulheres, necessário se faz pensar o campo religioso de suas atuações: a 
Umbanda e as múltiplas formas do exercício da fé, chamado por nós de Pedagogia do Terreiro.

A Umbanda no Brasil é uma prática religiosa que flui como um grande espiral, sem que se possa mensurá-la por dogmas ou regras rígidas. Neste sentido, esta religião se faz e se refaz pautada por um sagrado que se articula, diretamente, ao trânsito religioso.

Ora, o saber difundido nas religiões afro-brasileiras é regulado pela observação e assentado na intuição ancestral. Desta forma, nasce da conexão estabelecida com o astral, indicando o como praticar e como se conectar com os mentores espirituais (Pretos Velhos, Caboclos, Exus, etc.). Os milhares de Terreiros existentes por todo o país, reinventam práticas e rituais de forma independente e livre, estabelecendo uma pedagogia particular para interpretar e repassar o conhecimento do seu sagrado. Esta pedagogia se pauta nas urdiduras tecidas no interior dos Terreiros, com fios oriundos de diferentes registros religiosos - Kardecismo, Candomblé, Catolicismo, Catimbó, dentre tantos outros - e aqueles criados para atender, especificamente, o espaço religioso do Terreiro.

É nítido que cada Casa/Terreiro/Templo/Centro possui uma postura religiosa específica e diferenciada, aplicando uma metodologia ritual que não é rígida. Por este motivo, entendemos que nestes espaços se cultiva uma Pedagogia do Sagrado, definida como o conjunto de práticas rituais, pautadas 
nos saberes e nas experiências adquiridas no chão do Terreiro. Estas práticas formatam os rituais e sua ludicidade, estabelecendo os parâmetros de conexão religiosa entre os praticantes e as entidades, e entre as entidades e os consulentes, oportunizando ao mesmo tempo o entendimento da lógica espiritual que se concretiza através daquelas intermediações.

A título de exemplo, podemos lembrar que em toda "Gira" ou trabalho mediúnico, seja ele aberto ao público ou apenas aos iniciados, reside uma ação pedagógica carregada de dramaticidade e elementos simbólicos que, por serem identitários, referendam a energia que ali está sendo processada. Ao incorporar uma entidade, o médium assume características que possibilitam aos consulentes identificarem quem são as entidades em terra, naquele momento ${ }^{1}$. No caso dos Pretos Velhos, há a identificação pelo uso de cachimbos e cajados, pela dificuldade de locomoção e pelos corpos curvados, caracterizando pessoas mais idosas.

Entretanto, cada um desses elementos também possui uma função no ritual desenvolvido. O cachimbo, ao emanar a fumaça da queima do fumo, funciona como um volatizador de energias. O cajado, por sua vez, serve como elemento de limpeza astral que a entidade utiliza durante os passes, os

\footnotetext{
${ }^{1}$ Neste trabalho, a incorporação é entendida como o processo de conexão das forças espirituais ancestrais, manifestadas no corpo do médium por meio do transe.
} 
momentos de contato espiritual entre as energias das entidades e os frequentadores. Isto posto, observe-se que os elementos "cenográficos" não possuem apenas caráter identificatório. São, especialmente, ferramentas do trabalho mediúnico, do mesmo modo que as defumações, as rezas e outras práticas utilizadas no interior de cada Terreiro, durante os trabalhos religiosos.

Os elementos destacados acima, são exemplificações da existência, nos Terreiros, de uma pedagogia absorvida tanto pelos médiuns, durante o caminhar religioso; quanto pelos dirigentes, no processo de formação dos iniciados e do contato estabelecido entre praticantes e consulentes. No caso dos dirigentes, cabe a eles moldar a ação-atuação mediúnica em formação, a fim de proporcionar o encaixe nos moldes diretivos dos trabalhos espirituais desenvolvidos na casa.

É importante repisar, todavia, que não se trata de um padrão, um modelo a ser seguido em todas as Casas que professam a religiosidade afro-brasileira, dentro do registro da Umbanda. Cada espaço religioso aplica uma roupagem, com características específicas, direcionadas pelas entidades que se materializam num determinado momento ritual nos Terreiros.

Logo, a aplicabilidade de diretrizes ou normas rituais no viver e no praticar da Umbanda não é um processo rígido. Não existe um "passo a passo", uma receita seguida pelos praticantes, difundida em todas as casas do Brasil e que "padronize" a Umbanda. Suas práticas independem da 
aplicação de métodos, técnicas ou teorias, pois o "fazer" espiritual se dá no contato íntimo de cada sujeito com a sua espiritualidade.

Este processo individualizado, ocorre geralmente nos quintais das casas de zeladores, dirigentes espirituais responsáveis pela iniciação e desenvolvimento de outros indivíduos no universo da religião. Cada um constrói a sua relação íntima com a espiritualidade, seja aplicando a intuição ou adequando processos formativos pautados na observação e adquiridos no dia a dia do Terreiro.

Como regra, o que percebemos na maioria dos Terreiros é a existência de uma hierarquia assentada na vivência e na experiência dos praticantes. Os ingressantes neste desenvolvimento espiritual, são chamados de "cambones": os iniciantes em fase de adaptação para o desenvolvimento mediúnico. Apresentando um contato mais íntimo com o astral, mas ainda em situação de aprendizagem, temos os "médiuns iniciados" que poderão passar por um processo de experiência mediúnica. Este desenvolvimento durará em média sete anos, quando o médium receberá a graduação de "Pai Pequeno". Por fim, para se tornar sacerdote ou zelador exige-se um tempo maior. Este processo formativo, porém, não é rígido e cada casa religiosa, de acordo com suas necessidades e indicações espirituais, aplica sua metodologia de formação. 
Outro aspecto que merece destaque nesta Pedagogia do Sagrado, diz respeito ao papel da memória e da oralidade. $\mathrm{Na}$ Umbanda, a transmissão do conhecimento se dá oralmente. Por isso, a memória é um elemento fundamental para a manutenção e ressignificação da metodologia e da linguagem simbólica, utilizadas na manutenção do ritual da Casa e de seus seguidores.

Guias, patuás, águas bentas, plantas, pontos riscados, pontos cantados, vestimentas, incorporações, transes, são alguns dos recursos simbólicos que contribuem para a identificação de "quem é quem" no Terreiro de Umbanda. Mas, também permitem a construção de um sentido vinculante que, aplicado a esta religiosidade, conecta os sujeitos ao sagrado em suas múltiplas dimensões.

Por outro lado, ao visitarmos qualquer casa religiosa que pratica a Umbanda, em qualquer município brasileiro, nos depararemos com espaços constituídos de forma distinta. Alguns, com a presença de imagens de santos católicos ao lado de imagens de orixás africanos; outros, com símbolos e pontos riscados estampados nas paredes; ou, ainda, com um pequeno altar destacando a imagem de Jesus ou outro santo de devoção. Entretanto, as rezas, as defumações, as incorporações, os cheiros, as velas e a simplicidade dos lugares chamam a atenção para a sua recorrência. É este mosaico, ao mesmo tempo diverso e comum, que concretiza o lugar e o papel da 
religiosidade afro-brasileira na vida dos atores sociais. É neste espaço encantado que se dá a imersão no sagrado, estabelecendo a conexão entre os praticantes e o "acreditar".

Fios de contas, cores, cheiros, vestimentas e adornos, revelam e desvelam curiosidades e encantamentos. Trazem a estética do sagrado, a mística e a mágica para o lugar, fazendo aflorar a potência da Umbanda na vida de seus praticantes. A musicalidade, ressoada pelos atabaques e pontos cantados, dita o ritmo do fazer religioso praticado. Todos cantam, rodopiam, se misturam, compartilham das mesmas energias, ainda que experimentadas distintamente.

Para os "despreparados", não iniciados na mística do Terreiro, vivenciar seu compasso por certo gera estranheza. Mas, independendo da visão que se tem, o corpo é incitado a movimentar-se no ritmo das palmas, dos atabaques e dos cantos. Para viver a Umbanda plenamente é preciso senti-la. Assim, tanto visitantes quanto praticantes se envolvem no torvelinho inebriante de sensações e de ritmos.

Na Umbanda, os sons, os cheiros, sabores e toques integram a sua expressão religiosa. É por meio da experiência dos sentidos, partilhada no chão do Terreiro, que iniciados, graduados, consulentes, visitantes, experimentam o sagrado. É por meio delas que se mantém uma relação de reciprocidade com as entidades ancestrais, os seres divinizados, num processo contínuo de atualização da memória coletiva. Neste 
processo, se desconstrói a linearidade temporal do viver cotidiano, uma vez que o tempo cronológico nem sempre mensura o tempo do encantamento, ou seja, dos rituais ali desenvolvidos. É, pois, aquela relação que também define os marcos das histórias e das memórias dos praticantes, quando são incitados a falar do seu fazer religioso ou de suas experiências com o sagrado nas religiões afro-brasileiras.

As Giras e os ritos ditam o tempo do antes ou do depois, no cotidiano dos praticantes. Nesta lógica, o umbandista é o sujeito que melhor reelabora o tempo sagrado, pois é ele quem o pratica com mais intensidade. São nas ocasiões sagradas, que ele redimensiona nas funções do Terreiro, experenciando também momentos de aprendizagens e de fortalecimento do Axé; ou seja, da energia vital que alimenta a fé e revigora a relação do umbandista com o sobrenatural.

Na vivência e na experiência desses momentos, ocorre o movimento da memória, o reencontrar de histórias vividas, praticadas, silenciadas e reinventadas, funcionando como seiva que interconecta os sujeitos com a magia. Trata-se do alicerce testemunhal do tempo e da memória, nas vidas que se entrecruzam de perto e de longe, evidenciando as proximidades e as especificidades que apesar da distância geográfica revitalizam o sentindo plural da Umbanda.

Pensando neste trânsito religioso, no qual os sujeitos se apropriam de práticas e rituais e reelaboram suas histórias 
pessoais, pretendemos neste livro apresentar três momentos desta trajetória. Entendemos que eles permitirão aos leitores e leitoras, compreender melhor como essas práticas religiosas se evidenciam no exercício da mediunidade, mas também nas experiências dos praticantes com a família, a cidade, o bairro e a vizinhança, modificando o fluxo e o fazer religioso em diferentes contextos temporais e geográficos.

Assim, selecionamos de nossas pesquisas acadêmicas, desenvolvidas nos últimos anos, três trajetórias de vida e de fé, experienciadas em distintos locais do Brasil: duas, na cidade de Uberlândia, em Minas Gerais, na região do Triângulo Mineiro; e outra na cidade de Ji-Paraná, em Rondônia. Embora distantes no espaço e no tempo, são histórias que se entrecruzam. Apresentam especificidades e semelhanças e nos ajudam a pensar o tecido religioso afro-brasileiro como uma prática viva, alimentada pelo fazer de seus praticantes, geralmente mulheres que, na sua simplicidade, demonstram um envolvimento visceral com o sagrado e com o exercício da fé na reconfiguração da Umbanda no Brasil.

Os capítulos apresentados a seguir, abordam as relações de intimidade e de reconstrução de ensinamentos e aprendizagens, observando-as através das memórias. Trazidas à luz por narrativas orais, estas memórias partem dos sujeitos, de suas vivências e inquietações. 
Assim, no capítulo "Heranças da memória, histórias em reconstrução", evidenciamos o papel e o lugar das mulheres na Umbanda em Minas Gerais e como elas reinventam sua relação com o sagrado, enovelando-o à sua própria história. Já no capítulo "O fazer-se sujeito/mulher de Dona Maria Isabel da Silva", através de um patchwork de memórias e relatos de observação, procuramos retraçar a trajetória pessoal de uma das mais importantes zeladoras de Terreiro da cidade de JiParaná, em Rondônia. Finalmente, no capítulo "Da religiosidade popular às matrizes africanas: a Umbanda como lugar de fala" nosso objetivo é demonstrar como o reconstruir e o reinventar a Umbanda marcam as relações sociais tecidas dentro e fora dos limites das Casas religiosas, tomando como lócus o Terreiro de Mãe Isabel, em Rondônia.

Estas experiências, ainda que distantes geograficamente, nos permitem perceber as conexões possíveis, as especificidades do fazer religioso, as pedagogias tramadas e traçadas. E, nesta senda, como cada ator social reinventa as práticas umbandistas e as assume como reinvenção da sua própria vida.

Boa leitura!

Cairo Mohamad Ibrahim Katrib

Tadeu Pereira dos Santos

Rodiney Nunes de Oliveira 


\title{
CAPÍTULO 1
}

\section{Heranças da memória, histórias em Reconstrução}

\author{
A escrita é uma coisa, e o saber, outra. A escrita é a fotografia do \\ saber, mas não o saber em si. O saber é uma luz que existe no homem. É a \\ herança de tudo que nossos ancestrais puderam conhecer e que se encontra \\ latente em tudo o que nos transmitiram, assim como o baobá já existe em
} potencial em sua semente.

(Tierno Bokar, apud Bâ, 2003).

\section{Senhoras do sagrado na Umbanda em Minas Gerais}

A proposta de diálogo deste capítulo é refletir sobre o papel da memória na manutenção das histórias da Umbanda, em Minas Gerais, no Triângulo Mineiro. Em especial, as lembranças que povoam as recordações de mulheres dirigentes de templos religiosos, na cidade de Uberlândia ${ }^{1}$, cujas histórias se complementam no seu fazer religioso, exemplificando como elas desenvolvem metodologias para dar continuidade às heranças religiosas herdadas. Suas falas nos servem, também,

\footnotetext{
1 Uberlândia, localizada na região do Triângulo Mineiro/Alto Paranaíba, a 550km de Belo Horizonte/MG, é uma cidade com cerca de 600 mil habitantes e que foi fundada a partir do desbravamento das terras conhecidas como "Sertão da Farinha Podre", no final do século XIX.
} 
como processo de relembramento, por aguçar nossas memórias e recuperar novas e velhas impressões do vivido e do praticado na Umbanda, em Minas Gerais.

Recuperar estas falas nos levam ao nosso próprio exercício de memória, pois revivê-las é reencontrar novas possibilidades interpretativas. Desta forma, nos permitem compreender como saberes, fazeres e práticas no universo umbandistico, se recriam e se remodelam, objetivando a construção de um sentido para o "acreditar". Compreendido como um processo complexo, é um recurso que requer um mergulho sensível na diversidade da oralidade e da sua ressignificação em palavras escritas. Assim, trazemos de empréstimo as palavras de mulheres que protagonizam o exercício religioso para construir um entendimento de como elas se veem, se percebem e recriam a própria Umbanda.

Lidar com as histórias de outros, tentar amarrá-las através de um fio condutor, é um desafio. Ao mesmo tempo, falar delas, de suas impressões sobre a vida e sobre o exercício da religiosidade, também é. A tentativa de estabelecer uma compreensão deste universo, no qual a fé e o acreditar são possibilidades reflexivas sobre práticas religiosas, serve ao pesquisador como campo de investigação rico de significados. Neste sentido, as experiências religiosas afro-brasileiras podem ser relidas através dos modos e formas de apropriação, das suas mútiplas representações, por meio de seus processos de 
recriação e das pedagogias desenvolvidas; mas, também, pela ótica de quem protagoniza os saberes do Axé. Para nossa reflexão, estas nos interessam mais de perto.

A reconstrução do trajeto permitido pelas falas aqui eleitas, revelam muitas histórias. Vale lembrar, porém, que o revelado depende do desejo do interlocutor em permitir que os atores sociais falem, exponham sua intimidade e suas experiências com o sagrado. Entre o ouvir e o falar, é preciso o exercício da alteridade, da observação, da compreensão dos gestos, das atitudes, dos olhares e do entendimento das reticências contidas em cada ato de relembrar. Deste modo, as falas e o movimento mnemônico se revelam ao pesquisador com toda a sua subjetividade.

Por certo, o entendimento e a explicação para situações que envolvem a relação com o sobrenatural, é uma tarefa complexa, pois, por mais que a conexão com o sagrado faça parte da condição humana, ao mesmo tempo a transcende. Dito de outra forma, o espiritual ou o sobrenatural integram a vida dos seres humanos na terra, permitindo, igualmente, "ir além dela".

Os sujeitos sociais, cuja ótica nos permitiu enxergar aspectos da pedagogia sagrada de Umbanda, são mulheres, negras, trabalhadoras e religiosas. Mães, esteio do lar, são senhoras cujas raízes culturais se fincam no seio familiar, mas foram plantadas com "mironga e dendê" no solo encantado dos Terreiros em que atuam. 
Nós as encontramos em diferentes momentos do seu cotidiano. Todavia, foi no espaço do sagrado, com seus paramentos, que percebemos seu protagonismo. Vestidas de branco, com suas guias e torços, elas nos receberam para falarem de si e para reafirmarem o que cada uma construiu e constrói em termos de história e relembramentos. Neste movimento, em que passado e presente se fundem, as identidades são realimentadas pelas experiências familiares, religiosas, sociais e políticas, vivenciadas por mulheres de ontem e do agora, no espaço e no tempo.

Por analogia, estas mulheres são como as grandes árvores do conhecimento ou, para usar uma expressão de Eliade (1992) "árvores do mundo". Mantenedoras do Axé, representam as raízes da cultura africana e, como árvores sagradas, são vestidas, enfeitadas com fitas coloridas, cobertas de tecidos, rodeadas por um círculo mágico como as gameleiras da cultura nagô. Ataviadas, se tornam símbolo de resistência e persistência da (re) atualização das heranças ancestrais.

Não por acaso, os mitos africanos nos contam que, por possuírem raízes extensas e profundas, as gameleiras plantadas nos Terreiros de culto africano, permitem a conexão entre mundos. Desta forma, por deterem o poder de romper a terra e atravessar o oceano, as raízes da gameleira ligam o mundo dos espíritos e o mundo dos humanos. De acordo com Lody (2006), esta relação simbólica sustentou as tradições 
religiosas afro- brasileiras, permitindo a sua manutenção. Por outro lado, ainda que Bastide (1973) interprete estas narrativas como lúdicas, também considera que estão integradas ao processo de manutenção das crenças e dos cultos de matriz africana. Assim, as gameleiras mantém simbolicamente aceso o ciclo das reencarnações, permitindo o contato entre vivos e mortos, propiciando que o mundo do sagrado se faça presente no plano terreno, por meio de uma ponte que tem na energia feminina, a força que sustenta o portal entre mundos.

Comparado com o papel exercido pelos sacerdotes homens, entre os séculos XVII e XIX no Brasil, a literatura acadêmica considerou como secundário o papel exercido pelas mulheres dentro da religiosidade africana e afro-brasileira. Atualmente, porém, estas leituras não mais se sustentam. A historiografia dedicada ao tema conseguiu observar que as mulheres - tanto africanas quanto suas descendentes recém alforriadas - que se dedicavam à sobrevivência familiar, indo às ruas com seus tabuleiros para a venda de quitutes, eram as mesmas que assumiam a liderança religiosa.

Coube à elas a transmissão geracional dos valores e dos saberes ancestrais, uma vez que os homens continuavam presos às amarras da escravidão. Seu protagonismo foi ascendente, como bem destacou Perrot (2001), pois elas souberam apoderar-se dos espaços que lhes eram deixados ou confiados, ampliando seu poder e sua influência. 
Por óbvio, as histórias de mulheres de fé não se fazem apenas de registros escritos. São constituídas de memórias afetivas, individuais e coletivas, de vontades e desejos, cujas narrativas são tão profundas quanto as raízes de uma grande gamelereira. É a herança de tudo! É o que move, o que recria, o que permite repensar os sentidos de viver a fé, na sua plenitude e no repassar incessante às novas gerações.

No esteio de uma tradição oral ancestral, elas contam e recontam histórias, exercitando a oralidade herdada e na qual os gestos, os toques das mãos, os olhos direcionados para o horizonte ou para dentro de si, tanto revelam quanto escondem aquilo que de mais íntimo as recordações permitem externar. $\mathrm{O}$ grande espiral da memória surge como um redemoinho, unindo tempos, sentimentos e recordações em um turbilhão de lembranças que vêm, são atualizadas, expostas ou guardadas novamente no baú da memória. Suas falas se encontram, se confundem, se misturam e se separam, para darem sentido às histórias, pois:

[...] quando o fio de uma narrativa, puxado através da memória, revela suas múltiplas pontas, várias histórias se cruzam e uma gama de interesses e significados levam [essas mulheres] a recordarem coisas além daquelas que desejavam. (GOMES; PEREIRAS, 2002,p.73).

Mulheres, mães, trabalhadoras, religiosas, negras. Dentre todos os adjetivos, a negrícia é a pedra angular de um protagonismo, que expressa o legado religioso herdado. Estas senhoras da fé, fazem questão de regar com profusa sabedoria 
a frondosa árvore da vida. Não obstante, igualmente nos estimulam "a jogar o jogo das representações", construído em um campo de disputas no qual se desafia o reencontrar-se consigo mesmo. Do lugar de fala da religiosidade, fala-se de si, das suas relações e dos seus pertencimentos, deixando transparecer no semblante os silenciamentos impostos, as perdas vividas, os sonhos não realizados. Sobre este pano de fundo, nosso diálogo se inicia com as formas de ler e rever a vida, trazendo à cena a missão religiosa de uma das mais importantes zeldoras de Uberlândia: Maria Irene Arantes.

\section{Mãe Irene de Nanã}

Maria Irene Arantes, "Mãe Irene de Nanã" ou simplesmente "Mãe Irene", é uma mulher para ser lida no plural. Sua história religiosa foi construída em uma caminhada de grandes ensinamentos, adquiridos no convívio com a avó, Irene Rosa, e com a mãe, Maria do Rosário. Mãe Irene é a atual responsável pela Tenda Coração de Jesus. Localizada na cidade de Uberlândia, em Minas Gerais, conta com 73 anos de existência.

Esta casa religiosa foi edificada no terreno de sua avó. Ao longo de sua existência, tornou-se lugar de morada, do aprendizado escolar, das experiências religiosas e do viver cotidiano. Foi neste espaço que Maria Irene iniciou-se na Umbanda, ainda no ventre da sua mãe carnal, Maria do Rosário. 
Segundo sua narrativa, sua missão espiritual foi iniciada aos sete meses de gestação, quando a mãe teve complicações na gravidez e os médicos consideraram que eram poucas as chances de sobrevivência. A narrativa também reconhece na avó, Irene Rosa, a responsável por sua trajetória religiosa. Foi com ela que Mãe Irene aprendeu os segredos do Axé e se fez no Santo.

Mãe Irene não desvincula sua história pessoal e de fé, dos laços familiares. Para ela, este é o esteio da sua construção religiosa e da sua referência identitária. A necessidade de referendar as heranças advindas dos saberes transmitidos pela avó, reforça a importância do feminino na construção de sua identidade cultural e religiosa. Além disso, quando Mãe Irene chama Irene Rosa para Ihe ajudar a falar de si, demarca o papel social e histórico de uma mulher que, mesmo não dominando as letras, foi um importante agente para a mudança da visão de mundo, da realidade familiar e, ainda, para o reconhecimento da Umbanda em Uberlândia, preparando vários líderes religiosos.

Muito mais do que uma umbandista defensora da religiosidade afro-brasileira, Irene Rosa se inseriu no cenário político da cidade transitando com facilidade entre seus espaços. Sua casa sempre foi extensão dos gabinetes de vários políticos da região como, dentre muitos outros, o Dr. Homero Santos, João Pedro Gustim e Renato de Freitas. Mulher visionária, preocupada com o futuro dos mais carentes, fundou uma escola 
de alfabetização nas dependências do Terreiro de Umbanda, para atender crianças de baixa renda. Neste projeto, conseguiu que o poder municipal arcasse com os custos das professoras que lecionavam no local. Foi ela também quem apresentou a Umbanda e o culto aos Orixás à população de Uberlândia, realizando procissões, caminhadas e eventos religiosos na cidade.

Conforme Verger (1992), as mulheres negras envolvidas na lideranças dos Terreiros, têm muito das mulheres africanas, em especial o espírito da liderança, da autoridade e do comando, transmitidos ao longo da história, o que claramente percebemos na narrativa de Mãe Irene sobre sua avó, Irene Rosa.

De outro lado, tanto Irene Rosa quanto Maria Irene Arantes adentraram o mundo umbandista à procura de cura para uma enfermidade. Dessarte, foi esta busca que inseriu avó e neta no universo do sagrado e da fé.

Fazer-se umbandista para Mãe Irene foi um processo iniciado no ventre da mãe, sua trajetória e sabedoria são, hoje, o que esteiam suas ações à frente da casa espiritual que coordena. Assim, vida cotidiana, familiar e espiritual se misturam, nos lembrando as reflexões de Segato (2000) para quem a composição dos laços de pertencimento de quem se insere na religiosidade, se dá muito mais com a família de santo do que com a família de sangue. No caso de Mãe Irene, essas 
duas dimensões não se separam, o que leva a um exercício cotidiano de ação-interação religiosa-familiar, pois a família da Umbanda e a família consaguínea estão inseridas no mesmo espaço.

Em sua narrativa, Mãe Irene insiste que a sua vida pessoal e a sua vida religiosa estão posicionadas lado a lado. No entanto, é nítido que elas não se separam. Um dos fatores que contribuem para esta mescla é o quintal de sua casa. Desde a sua infância, este tem sido um espaço compartilhado. À época de sua avó foi o quintal de seus pais e hoje é o seu, de suas irmãs, filhas e sobrinhos.

Da mesma forma, é também o local do sagrado em que se encontra edificado o templo religioso de Umbanda. O lugar de vivência é também o da fé e, com isso, os laços familiares se sustentam no mesmo chão. Casa e quintal são espaços do viver familiar de Maria Irene Arantes e, também, campo sagrado que fundamenta o sentido religioso de Mãe Irene de Nanã. Este trânsito, que interliga vida cotidiana e missão religiosa, não é simples de desatrelar. Suas narrativas pessoais tem estreita relação com sua vivência religiosa e os caminhos que essa religião seguiu ao longo de sua consolidação no país, compõem sua história de vida, seu discurso e sua identidade sociocultural.

São muitas as formas de reler a importância do sagrado e a relação estabelecida com ele. Neste aspecto, o que mais nos chama atenção é a sua configuração simbólica e a manutenção 
dos seus sentidos. No caso da Umbanda, compreendida como marca cultural da religiosidade brasileira, percebemos a existência de uma metodologia ritual diversificada, presente nas práticas e saberes herdados. Estes, por sua vez, contribuem com a sua simbologia através dos encontros com o Catolicismo, o Kardecismo e outros registros religiosos. As experiências rituais vivenciadas na Umbanda pelos seus seguidores, movimentam a recriação dos seus sentidos ao longo de sua própria trajetória. Com Mãe Irene não foi diferente. Seu aprendizado reflete uma série de práticas. Sua família teve suas primeiras experiências espirituais no Kardecismo, migrando depois para a Umbanda. É o que revela a religiosa, ao inserir a experiência de sua avó, genericamente, no "espiritismo".

Ao abrir a sua casa espiritual, Irene Rosa se inseriu em um movimento religioso que ganhava dimensões significativas pelo interior do país. Neste processo, tradicionais Casas de Umbanda ainda em funcionamento, surgiram como a Tenda Coração de Jesus, em edificações construídas no fundo dos quintais ou improvisadas em algum cômodo das casas de seus praticantes.

A narrativa de Mãe Irene de Nanã nos ajuda a compreender o processo de desenvolvimento da Umbanda no interior do Brasil, bem como a aceitação das entidades espirituais que se humanizaram para se aproximar dos consulentes. Neste sentido, ao reportar a trajetória terrena e espiritual do mentor da 
sua Casa religiosa - o "Preto Velho Pai João da Bahia" -, explica que ele rege o seu viver e que ela se orgulha em poder servi-lo. Também destaca que o vínculo com a espiritualidade herdou de sua avó, pois Pai João da Bahia era também a entidade que ela incorporava. Com a sua partida, a entidade escolheu o seu aparelho, ou seja, o seu corpo físico, para se manifestar. Desta forma, perpetuou os trabalhos deste mentor na Casa de Umbanda que ela comanda. Além disso, Mãe Irene compara a escolha de ser a porta voz desta espiritualidade como o trabalho de um jardineiro que planta, cuida e contempla a árvoré da fé que frutifica e se torna frondosa.

Segundo Mãe Irene de Nanã, sua avó - Mãe Irene Rosa, ou simplesmente "Ireninha" - recebeu pela primeira vez a manifestação de Pai João da Bahia, no início da década de 1940. Posteriormente, com o falecimento da avó, a Tenda Coração de Jesus ficou sob a responsabilidade dos seus pais. Entretanto, como sua mãe estava muito doente e seu pai carnal, logo em seguida, fora acometido por um derrame, tiveram que passar o comando da Casa para Pai Roque Silva. Depois de 22 anos, Mãe Irene de Nanã assumiu o comando do local: quando terminou suas obriagações religiosas e se viu pronta para assumir a batuta, o comando da Casa Ihe foi entregue. A história de vida de Mãe Irene se confunde com a história do Terreiro. Vida cotidiana e vida religiosa mais uma vez se misturam, tecendo os fios que ligam passado e presente numa mesma dimensão. 
Mãe Irene mantém seus laços identitários plantados no chão do Terreiro, retroalimentados pelos laços afetivos com as mulheres de sua família, em especial com a avó. Segundo seu entendimento, em outras vidas pode ter sido "filha de sua avó", pois a intimidade e a cumplicidade das duas eram muito maiores do que as que mantinha com a mãe carnal, Maria do Rosário.

Ao lembrar das histórias compartilhadas com ela, Mãe Irene reforça os vínculos familiares e os atualiza, tendo como referência de memória um cachimbo utilizado por sua avó e que agora the pertence. Este elemento nos remete à leitura de que a memória é um fenômeno fortemente atrelado à identidade dos atores sociais, remetendo sempre a indivíduos, coletividades, lugares (POLLAK,1992) e por que não dizer a objetos, situações, odores.

O apego de Mãe Irene ao cachimbo, objeto que atravessa o tempo e a religa à memória da avó, integra a trama da sua narrativa. Conforme preoniza Ricouer (1994), a construção da narrativa é o processo que promove o encontro do passado com o presente e que permite aos indivíduos rememorarem os tempos idos, de forma dinâmica. Dessarte, a narrativa mnemônica é conduzida pelo fazer humano, atualizado pelas falas do vivido, mas que se dá para além do tempo cronológico. Afinal, é o caráter temporal da experiência humana que faz do mundo exibido um mundo inserido no tempo.

[...] e o tempo torna-se tempo humano na medida em que está articulado de modo narrativo: em compensação, a narrativa é 
significativa na medida em que esboça os traços da experiência temporal”. (RICOUER 1994, p.15).

Não obstante, relembrar o passado faz com que Mãe Irene demonstre certa preocupação em relação à transmissão do legado da avó. No entanto, prefere se omitir sobre quem deverá ficar com a responsabilidade de levar adiante os ensinamentos espirituais da Casa, quando não mais tiver forças para o cumprimento da sua missão. Para Mãe Irene, a escolha espiritual já foi feita e "Pai João da Bahia" já sabe quem está preparado para a missão, afirmando que: “[...] poderá ser uma das minhas filhas ou qualquer médium da corrente".

É evidente que a maioria das Casas religiosas afrobrasileiras tem no seio familiar seu grande alicerce. Sem fugir à regra, em seus setenta e três anos de existência, a Tenda Coração de Jesus recebeu dos laços familiares a energia vital para a manutenção do seu Axé. Da mesma forma, estes laços se tornaram o esteio de vários Terreiros que saíram dali, como a "Tenda São Lázaro Força e União Pai Domingos de Guiné", uma das muitas Casas de Umbanda que herdaram o Axé de Mãe Irene Rosa.

Se o chão do Terreiro agrega as forças do astral e conecta homens e mulheres ao sagrado, isto ocorre porque é um local de encontro dos atores sociais. Ali eles reconstroem suas histórias e seguem adiante, protagonizando outras narrativas de vida e de fé. A Casa espiritual de Mãe Irene 
exemplifica bem esse processo, pois ela é referência em se tratando da Umbanda em Uberlândia.

Muitas das pessoas que passaram e passam por ali, vão em busca de soluções que o plano material não conseguiu oferecer. Uns recebem suas graças e seguem suas vidas. Outros, recebem o chamado, ficam, e mais tarde assumem a missão de dar prosseguimento àquilo que aprenderam na Umbanda: levar o amor e a caridade às pessoas. São histórias que se complementam, vidas que se cruzam, sentidos do viver que se reforçam pelos laços da fé e do acreditar. Foi assim com Gessy Balbina - "Mãe Gessy de Omolu".

\section{Mãe Gessy de Omulu}

De acordo com as narrativas coletadas, em certo momento da vida Gessy Balbina se viu acometida por uma doença. Recorreu à medicina tradicional sem obter êxito. Uma prima de seu esposo, vendo sua aflição, propôs ajudar the dizendo que a cura de alguns males que os homens não curam, a espiritualidade curaria. O marido de Gessy, mesmo sendo evangélico, não se opôs em levá-la a uma casa religiosa de Umbanda e conduziu-a à Tenda Coração de Jesus, de responsabilidade de Mãe Ireninha.

Dona Gessy passou a frequentar as sessões mediúnicas, melhorando a cada dia. Como já estava ali há muito tempo, Pai João da Bahia - mentor espiritual da Tenda-, revelou 
que havia chegado a hora dela desenvolver sua mediunidade. $\mathrm{E}$ assim ela o fez. Atendeu ao chamado espiritual com o consentimento do esposo, que aceitou, também, que os filhos seguissem os passos da mãe.

Os doze filhos de Gessy a acompanharam pelo mundo da espiritualidade, fazendo o seu Axé em diferentes Terreiros. Alguns anos mais tarde, quando ela já havia conquistado a sua "feitura", ou seja, cumprido suas obrigações com o Axé por sete anos, foi avisada de que deveria ter seu próprio Terreiro para praticar a caridade. Juntamente com seus filhos, aceitou a responsabilidade, cumprindo o que os mentores espirituais designaram e começando o processo de preparação para a abertura de seu Axé.

Gessy Balbina foi uma das médiuns mais aplicadas da Casa do Preto Velho Pai João da Bahia. Conforme nos foi contado, mesmo frente às dificuldades financeiras, não mediu esforços para tornar realidade a missão que lhe havia sido delegada. Em 11 de outubro de 1998, inaugurou sua casa, em um terreno cedido por uma de suas filhas, Maria das Graças Silva.

Mãe Gessy ficou à frente do Terreiro até 2006, quando veio a falecer. Dos filhos que a acompanharam na missão religiosa, Selma Maria e Maria das Graças foram as escolhidas, pelos guias espirituais, para assumirem o comando da Casa, o que era um diferencial em relação à maioria dos Terreiros de Umbanda. Também as filhas de Mãe Gessy não mediram 
esforços para dar prosseguimento à missão da mãe e, mesmo com dificuldades, mantém a Casa em pleno funcionamento.

Dentro das narrativas que registram o protagonismo espiritual de Mãe Gessy, ela é apresentada como um exemplo de umbandista, que soube honrar os ensinamentos herdados no chão do Terreiro, desenvolvendo ações sociais e de caridade. Pessoas de bairros bem distantes vinham ao seu encontro, em busca de benzeções e da sua reconhecida sensibilidade mediúnica. Dentro do seu cotidiano, cumpria os afazeres domésticos e, todos os dias, saía em busca de doações. Dividia o pouco que tinha com quem a procurava e não faltaram palavras amigas par os aflitos, em busca de lenitivo para os sofrimentos da alma. Nas lembranças que a atualizam, descobrimos que embora fosse uma mulher de poucas palavras, Mãe Gessy sabia como utilizá-las para auxiliar o próximo.

Este caminhar, muito mais que um processo de crescimento espiritual, foi também uma forma de ressignificar e transmitir seu legado aos filhos. Luiz e Elias aperfeiçoaram a arte do batuque dos tambores, se tornando Ogãs ${ }^{2}$. Luiz herdou da mãe, o dom de criação dos pontos cantados. A maioria dos filhos se tornou pais e mães da Casa, estreitando os laços familiares e vivendo continuamente a Umbanda.

Das sete mulheres da familia de Mãe Gessy, seis têm funções diretas no Terreiro e apenas uma não frequenta a

\footnotetext{
${ }^{2}$ Aqueles que cantam e tocam atabaque.
} 
corrente mediúnica. Mãe Selma e Mãe Maria das Graças são as zeladoras da Casa e colocam em prática o que aprenderam com a mãe. Sebastiana foi a filha escolhida para ser a responsável pelas comidas nos dias de festas, preparação dos banhos, das ervas usadas nos rituais e por assistir o Preto Velho Pai Domingos de Guiné, quando está em campo, no Terreiro. Juscélia é a responsável pela comida dos santos e oferendas; Célia exerce a função de "Abá das Almas", aquela que cuida da manutenção das energias dos quartos de força, que fortalecem a Casa. É também ela quem administra o Terreiro, organiza o calendário de atividades e rituais, recepciona e direciona a assistência durante os ritos públicos.

Ao compartilharmos estas histórias, percebemos que a religiosidade é o que permite a estas mulheres recomporem a urdidura das experiências aqui contadas, recontadas e por nós interpretadas. Suas vozes expressam, em uníssono, a defesa dos cultos afro-brasileiros subsumindo sua própria individualidade em um coletivo atuante no grande palco da existência. Elas se veem como muitas mulheres em uma só e, quando são solicitadas a distinguirem a mulher, a mãe, a religiosa que cada uma é, a resposta vem mergulhada em reticências. Do mesmo modo que estas mulheres têm vidas cruzadas e histórias entrelaçadas, quando reconstroem suas trajetórias individuais de vida, a mulher e a mãe não se desvinculam da religiosa, pois se ligam intrinsecamente. 
Assim, no amplo campo da religiosidade afro-brasileira, a Umbanda se refez e se refaz a partir da experiência sócio histórica dos seus praticantes, sujeitos sociais que retecem suas memórias, dando sentido aos pertencimentos e permitindo a homens e mulheres um constante trânsito pelos saberes herdados. O lembrar atualiza o conhecimento do sagrado, promove a sua reelaboração e referenda a memória ágrafa, presente nos cultos e rituais, ressignificando os sentidos e os significados da prática umbandista. Neste processo, mantém o Axé das casas religiosas, reescrevendo no grande livro da vida experiências de sensibilidade, de intuição e do fazer-se sujeitoobjeto-enredo da própria história. 
CAPÍTULO 2

\title{
O fazer-se sujeito/mulher de Dona Maria Isabel da Silva
}

\begin{abstract}
[...] há muitos modos de induzir ao esquecimento e muitas razões pela qual pretende provocá-lo. O "apagar" não tem a ver só com a possibilidade de rever, a transitoriedade, o crescimento, a inserção de verdades parciais em teorias mais articuladas e mais amplas. Apagar também tem a ver com esconder, ocultar, despistar, confundir os vestígios, afastar da verdade, destruir a verdade.
\end{abstract}

(Paolo Rossi, 2010)

\section{A arte de sobreviver à luz da religiosidade popular em Rondônia}

Viver o sagrado afro-brasileiro no Brasil, muitas vezes implica em uma existência silenciosa. Trata-se de uma opção pela sobrevivência, feita por adeptos e templos face à imposição de dogmas "estatisticamente" proeminentes, como o catolicismo e as práticas evangélicas, principais referências na atual geografia do sagrado. Na contramão deste processo, a trajetória de fé de Dona Maria Isabel da Silva corrobora, como exemplo, o que muitos estudiosos vêm apontando nos últimos anos: as estatísticas não exprimem a pluralidade religiosa do país e, menos ainda, o papel significativo das religiões de matriz africana no mapa religioso brasileiro. 
A trajetória de nossa interlocutora é plural. Ela foi zeladora de um Terreiro de Umbanda, na cidade de Ji-Paraná, em Rondônia. Adepta das crenças afro-brasileiras, seu aprendizado se deu na vivência do Terreiro, mas também através de experiências espirituais dadas em diferentes registros. Fosse na "mesa branca" do Kardecismo, aplicando os saberes das ervas e da curanderia indígena ou, ainda, ressignificando um pouco de cada saber, contribuiu para a concretização do exercício espiritual na Umbanda, na região Norte do Brasil.

Lembrar o cotidiano de Dona Maria Isabel, nos impõe refletir quem foi esse sujeito sócio-histórico. Mulher, negra, de pouquíssima formação escolar, mas de uma grande sensibilidade no trato da religiosidade afro-brasileira, fez da imersão no universo umbandístico o seu porto seguro. A Umbanda se tornou seu alicerce e armadura, para lidar contra o preconceito e a discriminação, desvencilhando-a do olhar punitivo da sociedade que não lhe oportunizou o exercício pleno da cidadania.

Maria Isabel da Silva não existe mais como presença física, pois faleceu em 2019. Sua existência se faz no campo da memória, pois deixou sua marca no calendário da religiosidade de matriz africana, como uma das mais expressiva das(os) zeladoras (es) de Terreiros, no estado de Rondônia. Ela foi capaz de sair do anonimato, deixando de se esconder atrás dos 
muros de sua residência, para ser presente nas vidas e memórias daqueles que a ela recorriam, a fim de curar as feridas da alma ou da matéria.

Nossa proposta de interlocução com suas memórias, é perceber suas transformações e, ainda, até que ponto a narrativa mnemônica permite refletir sobre a sua imersão na religiosidade como um processo e suporte de sobrevivência.

Dimensionamos suas vivências por meio de pistas e rastros, vestígios deixados no tempo, discerníveis no presente e indicativos das suas experiências. Dentre estes, também podemos identificar pistas sobre as tentativas de silenciamento, uma vez que a vivência pública da sua espiritualidade conflitou com os interesses de outros grupos e sujeitos sociais. Estas experiências complexas, trazidas pelas memórias, nos permitem entrever a trajetória de Dona Maria Isabel conforme a perspectiva apresentada por Paul Ricoeur:

[...] Mais precisamente o historiador fica a meio caminho da definição inicial do vestígio e de sua extensão a uma coisa. São os homens do passado que deixaram sinais; mas são também os produtos de suas atividades, suas obras, portanto, coisas que Heidegger diria dadas e maneáveis (ferramentas, moradas, templos, sepulturas, escritos) que deixaram uma marca. [...] O vestígio indica aqui, ou seja, no espaço, e agora, ou seja, no presente, a passagem passada dos vivos; ele orienta a caça, a busca, a pesquisa, a investigação. Ora, a história é tudo isso. Dizer que ela é um conhecimento por vestígios é recorrer, em última 
instância, à significância de um passado terminado que, no entanto, continua preservado em seus sinais ${ }^{1}$.

Os vestígios que perseguimos bravamente, também reavivem aspectos inerentes à vivência da religiosidade de matriz africana e, também, de outras práticas populares alimentadas nos poros e às margens da sociedade. Enquanto tal, ainda vivem à mercê dos padrões religiosos brancos e cristãos, sujeitos à intolerância e à demonização. A despeito disso, são expressões intrínsecas da cultura e referenciais do sagrado para a maioria da população, que vive no estado de Rondônia.

Em se tratando da Umbanda, nossa pesquisa corrobora a literatura sobre o tema. Observamos que também em Rondônia, não se trata de uma religião única, mas uma prática embebida de diversas outras expressões do sagrado, (res)significadas em diferentes momentos da liturgia: pelo transe mediúnico, pela entoação dos cânticos e orações do catolicismo, pela sutileza das manifestações espirituais kardecistas; na fruição de águas e objetos, nos brados e gritos dos caboclos que, sonoramente, adentram os Terreiros.

Estes aspectos integram uma complexa Pedagogia do Sagrado, que se atualiza nas narrativas mnemônicas de Dona Maria Isabel. Por sua vez, estas expressam em gestos e

\footnotetext{
${ }^{1}$ RICOEUR, Paul. A memória, a história, o esquecimento. Campinas: Editora da Unicamp, 2007, p. 304.
} 
palavras uma série de recordações que se anelam no outrora e no agora, trazendo ao proscênio da narrativa também uma interpretação política da história recontada. Não uma história única, claro. Mas, refeita como um grande patchwork, composto por pedaços do passado, costurados no presente e que, ao constituírem o estofo das recordações, recompõem sua trajetória e dão sentido ao presente no qual se situam.

Dentro desta perspectiva, Dona Maria Isabel Pereira da Silva emerge das narrativas também como interlocutora. Através das memórias que a presentificam e que foram compartilhadas conosco em seus últimos meses de vida, nos foi possível retraçar suas experiências de mulher negra, pobre e religiosa. Suas histórias se confundem com as narrativas da cidade e do próprio estado de Rondônia, especialmente no que diz respeito ao fazer e refazer da religiosidade de matriz africana, prática de numerosos atores sociais que ali vivem, mas que a exercem anonimamente, no silêncio intramuros dos Terreiros.

A trajetória de Dona Maria Isabel foi tecida no tempo, em diferentes territórios do país. Seu deslocamento geográfico foi fundamental para cimentar sua construção identitária como sujeito. Percorreu a Bahia, o estado de São Paulo e o Paraná, até se instalar definitivamente no estado de Rondônia-RO, na cidade de Ji-Paraná em meados da década de 1960. Ali permaneceu até o seu falecimento, em 2019. Por outro lado, as diversas facetas da sua identidade como sujeito - mulher, negra, 
umbandista, trabalhadora - e que integram as suas vivências sociais, produziram múltiplas memórias a seu respeito, por diferentes sujeitos. Estas, se dão fora da linearidade, pois compostas no interior de temporalidades elásticas. Além disso, os significados presentes na constituição e reconstituição das lembranças pessoais de Dona Maria Isabel também explicitam os conflitos, as marcas da intolerância, da discriminação e do preconceito, mas, também, da sabedoria e das ações de resistência.

Isto posto, é nosso objetivo apresentar a sua trajetória de vida, procurando lançar luzes sobre as formas pelas quais Dona Maria Isabel foi se construindo historicamente como filha, adolescente, adulta, mãe, integrante da religiosidade católica, da Umbanda, até se tornar uma zeladora de Terreiro. Neste movimento, entendemos que será possível iluminar aspectos da experiência coletiva, uma vez que os códigos sociais que fundamentaram o seu modo de vida, revelam a multiplicidade de experiências e vivências da comunidade negra em Rondônia. Outras memórias da negritude foram e ainda são possíveis de serem materializadas, se tomarmos como referência suas próprias representações. 


\section{Uma mulher em trânsito: entre Bahia, São Paulo e Paraná, a arte de sobreviver}

A história de Dona Maria Isabel tem origem no estado da Bahia, onde nasceu. Ela veio ao mundo físico no dia 15 de outubro de 1942, em um sítio, localizado no interior da cidade de

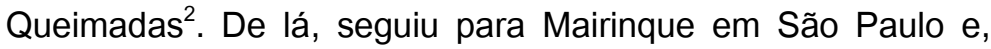
depois, no início da década de 1960, deslocou-se para Terra Rocha, no estado do Paraná. Ali permaneceu até 1963, momento em que migrou para Rondônia-RO e passou a residir na cidade de Ji-Paraná.

A família de Dona Maria Isabel não escapava do padrão das familias pobres do país. Era composta por seis filhos: Antônia, Loriano, Jacinto, José, Geraldina e Maria Isabel. Por sua vez, ela era a mais nova das filhas mulheres do casal, formado pelo lavrador Izidoro Vieira da Silva e a doméstica Maria Pereira da Silva. À luz das suas próprias lembranças, Dona Maria Isabel nos narrou as histórias que ouviu contar acerca de seu nascimento:

[...] tem vivo na memória que quando a parteira chegou, a mãe já tinha forrado o chão e colocado e no momento que ela chegou a bebezinha estava mamando o dedo [dona Isabel fez o gesto de mamar o dedos e em seu rosto um sorriso]. (Informação verbal) ${ }^{3}$.

\footnotetext{
${ }^{2}$ Queimadas possui uma área de $2.105,97 \mathrm{~km}^{2}$. Dista $300 \mathrm{~km}$ de Salvador, capital da Bahia e $4.000 \mathrm{Km}$ de Ji-Paraná.

${ }^{3}$ Informação fornecida por Dona Maria Isabel, durante o trabalho de campo realizado em 20/08/2018.
} 
As dificuldades materiais sempre foram uma constante. Ela se recorda que viveu grande parte da sua vida numa realidade desprovida de infraestrutura básica e serviços de saúde. A casa em que nasceu e passou sua infância era bem simples, de chão batido, sem água encanada e rede de esgoto. Não havia nenhum luxo, até porque "ter comida na mesa todos os dias" já era um grande privilégio.

Nos fios das lembranças, a pobreza ocupa a centralidade das recordações. Suas imagens assumem diferentes tonalidades, na relação dialógica que estabelece entre presente e passado. Assim, a narrativa da infância é marcada pela dor, pela tristeza e pela carência material:

[...] lembra que teve uma infância, no sítio, muito difícil, passava muita necessidade em todos os sentidos, recorda a existência de muitos animais selvagem, inclusive, onça na localização que costumava a rondar a casa e por isso os pais tinham que ter um cuidado especial com as crianças, recorda que a casa onde morava foi construída pelo próprio pai e era de chão batido, coberta com palhas e a lateral era feita de pau a pique e depois era abarrotada, era bem simples mais um lar que o amor entre as pessoas, os membros, não faltava (Informação verbal $)^{4}$.

Também a pobreza determinou a falta dos estudos pois, desde cedo teve que optar em ajudar nas lidas da roça ou estudar.

\footnotetext{
${ }^{4}$ Informação fornecida por Dona Maria Isabel, durante o trabalho de campo realizado em 20/08/2018.
} 
Não teve oportunidade nos estudos, conseguiu estudar até a $1^{\text {a }}$ série, pelo fato da única professora que tinha na localidade acabou indo embora, em busca de melhor condição de vida uma vez que o lugar não oferecia muitas oportunidades, e por ser distante da cidade não teve como continuar os estudos, hoje sabe mais ou menos escrever o próprio nome. (Informação Verbal) ${ }^{5}$.

Apesar da pobreza, a memória destaca as ações do pai e da mãe para protegerem a família, dos animais que cercavam a residência, bem como o carinho e a cumplicidade de todos. $O$ amor era o elemento que os unia no enfrentamento da miséria.

Pelo ângulo que Dona Maria Isabel escolheu para apresentar suas rememorações, a religiosidade funcionou, sempre, como uma das válvulas de escape que the permitiu esquecer, em parte, as dificuldades da vida. Foi na zona rural, onde viveu a infância, que ainda menina teve contato com várias práticas religiosas, sentindo-se fascinada pela riqueza de detalhes proporcionados pelo rezar e pela prática da fé. Deste emaranhado de lembranças, nas quais se articulam elementos do sagrado, também emergem os vínculos familiares e a proximidade com os pais.

$\mathrm{Na}$ recordação, o pai lavrador aparece como uma pessoa amorosa e que, por tradição familiar, aprendeu a arte da benzeção e da produção de remédios, utilizando os recursos da natureza para a fabricação das tradicionais garrafadas. Embora o dom da benzeção e o conhecimento da medicina popular não

\footnotetext{
${ }^{5}$ Informação fornecida por Dona Maria Isabel, durante o trabalho de campo realizado em 20/08/2018.
} 
fossem "comércio", seu pai recebia de bom grado as ofertas que Ihe eram dadas, complementando a renda derivada do ofício de lavrador e, desta forma, auxiliando no sustento da família. Em se tratando da mãe, a memória a apresenta como filha de indígenas. Ela cuidava dos filhos; mas, face à necessidade de manutenção da família, também acompanhava seu pai no trabalho da roça.

Por certo, apenas quem relembra é capaz de atualizar a memória, tornando-a um referencial na sua identidade. Não obstante, articula o tempo no processo de construção mnemônico, conforme sugere Antônio Astor Diehl:

[...] a noção de memória como identidade precisa estar envolvida com aqueles aspectos que proporcionaram o déficit da historiografia moderna: o tempo, espaço e o movimento. Dos múltiplos cruzamentos entre memória e identidade com as três variáveis poderão abrir outras tantas possibilidades para o estudo da história ${ }^{6}$.

À luz dos costumes da região, a experiência social e humana de Dona Maria Isabel tomou outros rumos, quando se casou. Foi um casamento "ajeitado", conforme a cultura da época e de "Queimadinho", nome que ela utiliza para se referir à localidade em que nasceu. Os pais arranjavam o casamento

\footnotetext{
${ }^{6}$ DIEHL, Astor Antônio. Memória e identidade: perspectivas para a história. In: Cultura Historiográfica: memória, identidade e representações. Bauru/SP: Edusc, 2002. Relativos às discussões da relação do tempo e a memória ver também: SEIXAS, Jacy Alves de. Os tempos da memória: (des)continuidade e projeção. Uma reflexão (in)atual para a história? Projeto História, São Paulo, v. 24, p.49, 2002b; PINTO, Júlio Pimentel. Os muitos tempos da memória. In: Projeto de História. São Paulo/PUC, n 17, 1998. pp. 203-211.
} 
dos filhos, inclusive entregando as filhas antes de atingirem a maioridade. Em conformidade com os costumes casou-se ainda menor, no civil, com Gabriel José da Silva, com quem viria a ter dois filhos: Valter e Edson.

No início da década de 1960, porém, todo o grupo familiar - incluindo Dona Maria Isabel, o marido e os filhos - se deslocaram para a cidade de Mairinque, no estado de São Paulo. A passagem por São Paulo, culminou na separação do casal. Sem o marido, ela e seus dois filhos seguiram o grupo familiar paterno para Terra Rocha, no Paraná, onde se estabeleceriam.

A partir das lembranças de Dona Maria Isabel, a cidade de Terra Rocha é "dada a ler" como um espaço da conquista, de melhores condições de vida e de oportunidades de estudo. Especialmente da irmã, que conseguiu se formar professora:

Em busca de poder proporcionar melhor condição de vida a família, Sr. Isidoro e Dona Maria, mudaram para a cidade de Terra Rocha no Paraná, levando consigo Dona Maria Isabel e sua família. Foi lá, em Terra Rocha, que seus irmãos tiveram oportunidade de estudar, inclusive uma de suas irmãs conseguiu ser professora, já ela por ter os filhos pequenos não teve como continuar os estudos, tinha que trabalhar também para ajudar no sustento das crianças, apesar que seu pai a ajudava. Seus irmãos permaneceram em Terra Rocha, local onde sepultaram seus pais (Informação verbal) ${ }^{7}$.

O aconchego da família sempre foi uma referência para Dona Maria Isabel. Contudo, Terra Rocha assumiu sentidos

\footnotetext{
7 Informação fornecida por Dona Maria Isabel, durante o trabalho de campo em 22/08/2018.
} 
distintos para ela e seus irmãos. Como se vê na informação verbal acima, foi nesta localidade que seus irmãos estudaram, enquanto ela precisou se submeter ao trabalho para garantir o sustento dos próprios filhos, embora pudesse contar com a ajuda dos pais.

Foi também em Terra Rocha que Dona Maria Isabel conheceu seu segundo marido, Silvino Antônio de Souza ${ }^{8}$. Em 1963, após o falecimento de seus pais, ela, o novo companheiro e os dois filhos seguiram para o Norte do Brasil, deixando seus irmãos para trás. Este novo deslocamento, se deu no contexto do surgimento de uma nova fronteira agrícola, resultante da inauguração da BR 364, em 1960, ligando São Paulo à região Norte, via Porto Velho ${ }^{9}$.

A nova estrada permitiu a migração de um grande contingente populacional, atraídos pela propaganda de um "eldorado" com múltiplas oportunidades.

Sonhando em melhorar de vida, Dona Maria Isabel e sua família se mudou para a cidade de Ji-Paraná em Rondônia,

\footnotetext{
${ }^{8}$ Ao longo da vida, Dona Maria Isabel teve três companheiros, nesta ordem: Gabriel, Silvino e Paulo. O terceiro viveu com ela até sua morte. À época deste trabalho de campo o Sr. Paulo, já viúvo, vivia na residência construída por ela, com a ajuda dos filhos e da comunidade de Terreiro.

9 Também conhecida como "Rodovia Marechal Rondon", a BR-364 foi inaugurada em 1960. É uma rodovia diagonal, que se inicia na cidade de Limeira, no estado de São Paulo, até a divisa com Minas Gerais. Depois, atravessa os estados de Goiás, Mato Grosso, Rondônia e Acre, terminando em Mâncio Lima, no extremo oeste do Acre. Trata-se de uma via terrestre fundamental para o escoamento da produção das regiões Norte e Centro-Oeste do Brasil.
} 
abrindo novo capítulo na luta pela sobrevivência. Contudo, a vida no extremo Norte do país Ihe reservou tragédias, maus tratos e miséria. Seu primeiro filho, Valter, viria a falecer, vítima da descarga elétrica de um peixe Poraquê ${ }^{10}$, ao se banhar no Rio Machado.

A vida com o novo companheiro, Silvino, foi marcada por reiterados episódios de violência doméstica. Longe da família, foi vítima constante de maus tratos. Silvino era um homem violento e acabou sendo preso em Rondônia pelo crime de homicídio. Ainda jovem, com trinta e dois anos de idade, Dona Maria Isabel se viu novamente sozinha com os filhos.

Silvino cumpriu dez anos de pena. Sua saída da prisão significou não apenas o retorno da violência à vida de Dona Maria Isabel, mas também da miséria. O ex companheiro passou a ameaçá-la, obrigando-a a vender sua casa para dividir com ele o montante financeiro, caso contrário daria cabo à sua vida e a de seus filhos.

Em 1974 o senhor Silvino foi embora para São Paulo depois de ter pago sua conta com a justiça por ter assassinado um cidadão, mediante isso ele exigiu da dona Maria Isabel que vendesse a casa e desse a sua

\footnotetext{
${ }^{10} \mathrm{O}$ Poraquê (Electrophorus electricus) é uma espécie de peixe elétrico que pode chegar a dois metros de comprimento e pesar cerca de vinte quilos. Sua capacidade de geração elétrica varia entre trezentos volts e 860 volts. O termo "poraquê" vem da língua tupi e significa "o que faz dormir" ou "o que entorpece", em referência às suas descargas elétricas. A espécie é típica da Bacia Amazônica e pode ser encontrada também em quase toda a América do Sul. Cf. https://web.archive.org/web/20070117232907/http://www.ufrpe.br/deolho/1998/deolho002.html
} 
parte em dinheiro caso contrário iria matar toda a família. (Informação verbal $)^{11}$.

Com a partida de Silvino para São Paulo, as ameaças e fantasmas de violência cessaram. No entanto, a miséria encontrou Dona Maria Isabel e seus filhos. A memória deste momento é de trabalho árduo, incessante e não menos brutal.

[Edinho]. [...] na época brincadeira quase não tinha, sempre tínhamos que trabalhar, trabalhar; aqui era chamado de vila de Rondônia e tinha pouca coisa, nosso objetivo era trabalhar, desmatar os lotes, quando meu padrasto mata a pessoa e vai embora aí viemos para a cidade, tivemos que vender as coisas que tínhamos para dividir com ele, minha mãe teve que levar o dinheiro onde ele estava (Informação verbal) ${ }^{12}$.

Também para Dona Maria Isabel, as opções de trabalho eram as atividades braçais, inclusive as de caráter pesado. Sua memória traz deste período o sofrimento, o desalento e as humilhação a que foi submetida:

[...] com essa separação ela precisou trabalhar pesado para manter a sobrevivência dela e dos filhos; ela conta que foi um período de grande sofrimento, lembra que teve que dormir ao relento, porque não conseguiu pagar o aluguel depois que o proprietário a colocou para fora de casa e tomou a cama e o colchão, como forma de pagamento do aluguel. (Informação verbal) ${ }^{13}$.

Foi com o trabalho que Dona Maria Isabel conseguiu garantir o sustento da família e também guardar algumas economias para comprar um lote. Deste espaço, passou a

\footnotetext{
${ }^{11}$ Informação narrada por Edinho filho de Dona Maria Isabel.

12 Informação narrada pelo Edinho filho de Dona Maria Isabel.

${ }^{13}$ Informação narrada por Dona Isabel e anotada pelo pesquisador em seu caderno de anotações. Trabalho de campo realizado em 07/06/2019.
} 
prover o sustento por meio do cultivo de hortaliças:

Com muita luta e sacrifício conseguiu comprar um lote e construir um barraco de madeira onde começou a plantar uma pequena horta e no final de semana ela saía para vender verduras que já produzia em seu quintal, trabalhava em restaurante na função de cozinheira, nesse mesmo período trabalhava como cozinheira em bares e restaurantes (Informação verbal) ${ }^{14}$.

A venda de hortaliças também faz parte das memórias do filho, Edson. Ao se lembrar desta atividade da mãe, igualmente se recorda dos seus próprios esforços, do irmão falecido e, ainda, da compaixão:

[Edinho]. [...] ela vendia verdura na rua, as pessoas que frequentava levava uma cesta, tem uma senhora que todo mês dava sacolão para ela, eu sempre ajudei o meu irmão que faleceu também, inclusive a casa que ela morava foram as pessoas que frequentava o Terreiro que ajudou a construir, ela não tirou um centavo do bolso para a construção. [...] Minha mãe tinha uma feira ali na vila do Jotão, cada um tinha uma barraquinha na beira da BR, ela vendi banana, verduras, legumes e eu trabalhava em uma máquina de beneficiamento de arroz, trabalhei mais ou menos uns oito anos com esse patrão, comecei a trabalhar tinha uns 16 anos, foi esse patrão que ajudou a comprar um ranchinho, lembro que quando chovia minha mãe tinha que nos cobrir com lona porque molhava tudo lá dentro. (Informação verbal) ${ }^{15}$.

Além das atividades descritas acima, Dona Maria Isabel também trabalhou como cuidadora dos filhos do Dr. Demétrio Bidá, proprietário do Hospital Santa Mônica. Por intermédio do médico, trabalhou no setor de limpeza do hospital. Foi neste

\footnotetext{
${ }^{14}$ Informação narrada por Dona Isabel e anotada pelo pesquisador em seu caderno de anotações. Trabalho de campo realizado em 07/06/2019.

${ }^{15}$ Informação fornecida por Edson, filho de Dona Maria Isabel. Entrevista realizada em 07/09/2019.
} 
momento que descobriu ter sopro no coração, um ruído produzido pela passagem do sangue pelas estruturas do órgão, podendo ser sinal de doença grave. As implicações da doença a levaram novamente ao desemprego:

[...] ele [o médico] pediu que eu ficasse em casa para descansar um pouco, passou os remédios, e fiquei tomando em casa, quando eu voltei já tinha outra pessoa em meu lugar, alegou que não precisava mais dos meus trabalhos, as pessoas me incentivaram a levá-lo na justiça para pagar os meus direitos e assim eu fiz, levei e teve que pagar todo meu tempo de trabalho que tinha direito, na época pagou CR \$100,00 (cem cruzeiros) para mim e o mesmo valor para o advogado. (Informação verbal $)^{16}$.

Quanto aos familiares que ficaram em Terra Rocha, no estado do Paraná, Dona Maria Isabel nos contou que nunca mais teve como visitá-los. Contudo, reconstruiu sua vida e encontrou um novo parceiro, Paulo. Mesmo assim, sua vida amorosa, os seus casamentos, sempre foram marcados por maus tratos. Edson Pereira dos Santos, filho mais novo do primeiro casamento, referenda essa realidade ao narrar os desencontros amorosos da mãe. Ele afirmou que ela:

[Edinho]. [...] não tinha um bom relacionamento com o padrasto, pois o mesmo sempre maltratava sua mãe, não proporcionava um ambiente higiênico para morar. O filho conta que devido ao acumulo de coisas não uteis, dentro e fora da residência, tornava o ambiente insalubre e impróprio para moradia, principalmente aos cuidados de pessoa idosa. Devido ser um espaço perigoso isso causou um acidente a Dona Isabel, onde foi lesionado gravemente o seu pé, o que veio a provocar um

\footnotetext{
${ }^{16}$ Informação narrada por Dona Isabel e anotada pelo pesquisador em seu caderno de anotações. Trabalho de campo realizado em 07/06/2019.
} 
tétano, levando a amputação de uma de suas pernas. (Informação verbal) ${ }^{17}$.

Por outro lado, ao reinserirmos o sujeito nas urdiduras sócio históricas que contextualizam a prática do sagrado afrobrasileiro em Rondônia, abre-se uma nova perspectiva de interpretação. A história de Dona Maria Isabel também é um convite para pensarmos a sua existência à luz da Umbanda, na cidade de Ji-Paraná. O seu fazer-se como mulher negra, mãe, trabalhadora, figura pública, política e umbandista foi singular. No entanto, também ilumina aspectos recorrentes da experiência religiosa e de vida de outras mulheres negras que, em Rondônia, praticaram e praticam a fé dentro da religiosidade de matriz africana.

Sua história nos ensina a perceber a força da Umbanda na luta contra os preconceitos, o racismo e a discriminação social. É um etos da sobrevivência, do seu transformar no e sobre o tempo, dentro do qual a solidariedade construída nos Terreiros, alimenta o fazer da comunidade negra ali presente. É, ainda, uma história produzida pelo reconhecimento e aceitação da comunidade negra, que precisou transformar o silêncio em um aliado para sobreviver à violência cotidiana, imposta pelas novas religiões que chegaram depois e ali se instalaram.

\footnotetext{
17 Informação fornecida pelo Edson Filho de Dona Maria Isabel. Entrevista realizada em 07/09/2019.
} 
Ao longo de quarenta anos, em Ji-Paraná, Dona Maria Isabel se alimentou nas práticas umbandistas. Sua experiência permite ao pesquisador problematizar 0 processo de constituição e reconstituição da Umbanda na localidade, de modo a conferir sentido ao bairro Primavera, lócus de diversos Terreiros na cidade.

A vida e a prática do sagrado, experenciados por Dona Maria Isabel, a inserem no próprio contexto do bairro, lugar de disputa e transição, num bairro-cenário que dividiu espaço e embates com outras religiões. Diferentes de outros, inclusive grandes, seu Terreiro sobreviveu, dinamizando a cultura do local.

A continuidade da prática umbandista no Bairro Primavera, vincula Dona Maria Isabel aos antigos Terreiros. Mas, ao mesmo tempo, a torna uma figura expressiva, plural e pública, fundamental para a vida de diversos atores sociais que se deslocavam até o Centro, em busca de socorro. Seu filho, Edinho, nos contou sobre as representações comuns dos moradores do bairro, demonstrando a importância assumida por Dona Maria Isabel em um espaço carente de recursos. Mas, são as palavras de nossa interlocutora que dão conta da sua relação com o outro, igualmente carente, no fazer-se cotidiano do Terreiro:

Depois que deixei de trabalhar fora, passei a dedicar exclusivamente ao Terreiro, não sou aposentada recebo um benefício é com ele e a ajuda de pessoas quem vem aqui inclusive você eu consigo viver. Não atendo as pessoas pelo dinheiro, se elas têm condição, paga, atendo, mas 
senão atendo do mesmo jeito, tem vez que tiro do meu para comprar os materiais para o trabalho. (Informação verbal) ${ }^{18}$.

Assim, a história de Dona Maria Isabel, não é "apenas uma vaga lembrança", como os discursos antagônicos, e em especial de registros religiosos conflitantes, querem fazer supor. No lócus de vivência e da experiência do sagrado impressas no bairro Primavera, sua história emerge sólida, nas narrativas dos sujeitos que ainda residem por lá. É uma história que reluz na vivência da comunidade negra, à luz da religiosidade de matriz africana que constitui o alicerce de seus modos de vida.

\footnotetext{
${ }^{18}$ Informação narrada por Dona Maria Isabel e anotada pelo pesquisador em seu caderno de anotações. Trabalho de campo realizado em 07/06/2018.
} 
CAPÍTULO 3

\title{
Da religiosidade popular às matrizes africanas: a Umbanda como lugar de fala
}

\author{
[...] as vezes dá um aperto assim, a gente olha tudo e fica aquela \\ lembrança muito grande dela [Maria Isabel], foram muitos anos de convivência ai \\ não tem como não lembrar, ainda mais trazendo tudo que era dela, fazendo os \\ assentamentos tudo aqui em cima, a gente fica lembrando de tudo das coisas boas, \\ dos sofrimentos dela que não foi poucas foram muitas. Ai a gente tem que ter força \\ para lutar e continuar a vida no dia a dia.
}

(MÃE ROSI, 2019).

O refúgio, a morada, a residência, o encontro com o sagrado, o local de agregação religiosa, o pronto socorro para sujeitos de plurais camadas sociais, são adjetivos que qualificam o Terreiro de Umbanda de "Mãe Isabel", situado na rua Xapuri, $n^{\circ}$ 898, no Bairro Primavera, na cidade de Ji-Paraná. Espaço singular, além de atravessar tempos, referenciando as histórias da negritude, foi, na região em que se inseria, o único Terreiro a ter como zeladora uma mulher, negra, responsável por perpetuar a tradição dos Orixás e Caboclos.

Ao longo da sua missão, Mãe Isabel fez vários filhos no Santo, os quais abriram novos Terreiros, difundindo a religiosidade de matriz africana em diferentes bairros da cidade 
de Ji-Paraná. Também visitou outros Terreiros e recebeu pessoas consideradas importantes, na cidade e seu entorno. Além disso, pela força dos Pretos Velhos, das demais entidades e dos santos, Mãe Isabel se tornou uma referência educativa para a prática da Umbanda. O seu Terreiro foi ativo por várias décadas, abrindo seus trabalhos por quase 40 anos. Sobreviveu ao racismo, ao preconceito e à discriminação; se firmou e se afirmou, produzindo aceitação, reconhecimento ou intensificando olhares de condenação.

O seu existir e o seu persistir, conferem sentido à Pedagogia dos Terreiros como prática que também politiza e leva à reflexão. Da mesma forma, promove a continuação de uma dada memória, cujas histórias permitem aos ouvintes acessarem os códigos e símbolos da comunidade negra, afirmando-se como sujeitos de direito. Neste processo, a religiosidade fundamenta os modos de vida como fruto da sua prática social. Por isso, o local, o espaço físico do Terreiro, revela bastante do constituir e reconstituir das significações da religiosidade da comunidade negra, nas diferentes tramas de sua tessitura social.

A presença material do Terreiro, dentro da geografia urbana de Ji-Paraná, também ensejou uma prática educativa aos transeuntes que por ali passavam. O espaço do Terreiro se constituiu em paisagem sagrada, produzindo representações que tangenciaram as experiências cotidianas dos sujeitos, bem 
como da própria Dona Maria Isabel no universo plural da Umbanda.

Em nosso entendimento, os Terreiros congregam narrativas que dão sentido às disputas em torno das práticas culturais, na sociedade brasileira. São lócus de afirmação e também de conflitos, pois vão na contramão de um padrão religioso assumido como universal, a despeito da laicidade do Estado e da liberdade de culto, garantidos pela Constituição Federal. Por ser parte de um modo de vida, situado no âmbito da comunidade negra, os Terreiros ainda são vistos de forma pejorativa, marginal, demoníaca.

No malabarismo da manutenção religiosa e pessoal, as trampolinagens se efetivam como uma prática de sobrevivência e de negociação. Dentro da sua experiência de vida, Mãe Isabel conseguiu interpretar a dinâmica social como campo de disputa. Inserida nesta dinâmica, teve sagacidade para perceber que embora não fosse possível "ganhar o jogo", era capaz de se "manter na partida". Dito de outra forma, para viver em harmonia com os diversos moradores do bairro Primavera e preservar os trabalhos de sua Casa Espiritual, Mãe Isabel deixava claro que a boa convivência era necessária. Esta era uma de suas maiores preocupações pois, por várias vezes, a polícia militar tentou barrar as atividades do Terreiro, devido às queixas dos vizinhos que se diziam incomodados com o barulho dos tambores. Assim, 
para se "manter no jogo", estabeleceu que os mesmos cessariam às $21 \mathrm{~h}$.

Em 2019, o cenário se modificou. O silêncio desceu no Terreiro de Mãe Isabel. Seu falecimento interrompeu os sons dos atabaques, dos pontos cantados, do brado do Caboclo, o cheiro do incenso, as velas em combustão, a fumaça da defumação. Toda uma dramaturgia de fé, esperança e resistência tornaram-se lembranças do passado de quem por ali "passou".

A sabedoria derivada da fé de Mãe Isabel e o modo com que ela orientava suas ações no Terreiro, são hoje fragmentos de memórias, atualizadas pela narrativa de frequentadores e filhos de fé, e, ainda, do próprio pesquisador em seu trabalho de campo. Através destas memórias, a Mãe de Santo renasce e, com ela, os sons, as cores, os sabores: toda uma pedagogia sagrada, que marcava o cotidiano do Terreiro.

Nas quartas feiras tinha a Gira aberta ao público, começava as $19 \mathrm{~h} 30$ e não tinha horas para terminar, só o uso do atabaque que as $21 \mathrm{~h}$ tinha que parar por causa dos vizinhos, ela tinha essa preocupação de não incomodar os vizinhos, durante a semana ela também atendia as pessoas, fazia as benzeções e ela sempre tirava nas sexta pra trabalhar na esquerda e nas quartas feira na mesa branca A Mesa Branca é a prática da mediunidade com base nos ensinamentos de Jesus Cristo, através de guias espirituais, que podem ser entidades ou espíritos de trabalho. onde os médiuns se dispõem para fazer as consultas espirituais. Nela, também podem ser colocadas oferendas ou pedidos aos guias. A cor branca é escolhida e utilizada para cura e purificação, além de simbolizar a abertura de caminhos. Era muito bom. (Informação verbal). 
Os trabalhos tinham horário para iniciar e finalizar. O ritmo seguia uma dinâmica particular, pois sua devoção aos Pretos Velhos, sua incursão astral e o modo de se relacionar com as identidades durante a Gira $^{1}$, se davam por meio de orações e da musicalidade manifestada ao som dos atabaques e dos pontos cantados. A sincronia das palmas, o ritmo ditado pela sinfonia das orações em forma de música, marcavam o tempo dos rituais e a permanência da conexão dos presentes com o sagrado.

A participação dos membros da casa e dos visitantes na Gira, deveria seguir as recomendações que orientavam os trabalhos da Casa. Neste sentido, as pessoas deveriam se atentar às vestimentas, conforme orientação de Mãe Isabel:

[...] o Terreiro de Umbanda é um local de culto, sagrado e, por isso mesmo, não aceitamos no Terreiro pessoas com roupas curtas ou justas, decotadas ou transparentes. De preferência as roupas devem ser confortáveis e brancas².

\footnotetext{
${ }^{1}$ GIRA é a reunião de vários espíritos, que se manifestam através da incorporação nos médiuns. Existem Giras para as determinadas linha da Umbanda, podendo ser uma Gira aberta, onde se atende a população e são conhecidas como "assistências"; e as Giras de estudo e desenvolvimentos conhecidas como Gira fechada, fechadas ao público. As Giras mais comuns em Terreiros de Umbanda são: Preto Velho: são cultuados os pretos e pretas velhas, entidades de negros e negras mais velhos. Caboclo: são diversas entidades como baianos, boiadeiros, marinheiros, malandro e Cigano. Erê: são as crianças, geralmente vêm na data de São Cosme e Damião. Esquerda: nessa gira são cultuadas as Pombas Giras, os E e eventualmente Exús Mirins. Gira de Cura. A Gira pode ser festiva, de trabalho ou de treinamento.

${ }^{2}$ Tais considerações foram produzidas por Dona Maria Isabel, que orientava os filhos e filhas do Terreiro a utilizarem roupas brancas para participarem da Gira.
} 
Mãe Isabel seguia toda uma metodologia, do início ao fim das Giras. Ela ficava sentada em uma cadeira, em frente a porta, recebendo as pessoas que iriam participar. Já na entrada, orientava os visitantes para observarem o local e aguardarem o momento de iniciação do rito, para depois falarem com as entidades.

O respeito pelo espaço era uma exigência. Não se permitia fofocas, vendas ou brincadeiras, pois conforme explicava Mãe Isabel, o local era destinado ao encontro com Deus. Assim, as pessoas deveriam permanecer em silêncio e se deixar envolver pelos rituais. Dentre estes, destacamos a sacralidade do solo, e, portanto, as orientações para pisá-lo: ao chegarem no Terreiro, as pessoas deveriam ficar descalças para descarregarem os maus fluídos. Por sua vez, aquelas que passavam a frequentar o Terreiro de Mãe Isabel deveriam encostar a cabeça no altar, como sinal de respeito à Deus, aos Orixás e às Entidades.

O chão do Terreiro era repleto de pontos riscados, velas branças e vermelhas, água e outros elementos que acionavam os comandos mágicos, aglutinadores da energia utilizada pelas entididades. Sobre esta cenografia sagrada, erguia-se o som dos atabaques e do canto, entoados pelo mestre (Ogã), fomentando a energia vibratória da Gira.

Além disso, é preciso destacar o espaço denominado de "cozinha", local em que a zeladora realizava os passes e demais 
trabalhos, o que exigia um vestuário confortável e de cores claras, como forma de reverência e respeito. Tais aspectos conferiam sentido aos diversos ritos, especialmente nos dias reservados ao público. Já os trabalhos internos da casa seguiam outras conotações, nos dias de festas ou dos trabalhos de iniciação.

Para além dos dias de ritos públicos, é preciso ressaltar que o Terreiro realizava os seus trabalhos ao longo da semana devido à grande procura. Frequentavam o Terreiro não apenas moradores da cidade de Ji-Paraná, mas também da região da Zona da Mata rondoniense e de outras cidades do estado. Ressalte-se, porém, que as leituras apresentadas pelos sujeitos acerca do Terreiro assumem significações diferentes, a depender da relação estabelecida com ele, bem como a sua imersão. Para o Senhor José Santana de Aguiar - morador do bairro Primavera desde o ano 2000, nas proximidades do Terreiro de Mãe Isabel - a leitura é marcada pelo distanciamento:

Quando mudei aqui pra Ji-Paraná, no bairro Jardim Primavera, esse Terreiro já existia; nunca fui participar, mas ouvia os batuques. Pensei que até tinha acabado porque depois de algum tempo não ouvi mais os batuques. Do tempo que moro aqui nunca ouvi ninguém fazer algum tipo de comentário nem positivo nem negativo". (Informação Verbal) ${ }^{3}$.

\footnotetext{
${ }^{3}$ Informações fornecidas pelo Senhor José Santana de Aguiar. Entrevista realizada em 07/09/2019, Bairro Primavera, Ji-Paraná-RO.
} 
Observe-se, no entanto, que a Umbanda e o sagrado dos Terreiros não são uma realidade distante para o narrador. Pelo contrário, o Senhor José Santana de Aguiar nos disse que sua primeira experiência com a Umbanda ocorreu em Porto Velho, cidade em que residia antes de se mudar para Ji-Paraná:

[...] meu ex-cunhado participava de um Terreiro, na época eu era casado, sofri um acidente e fraturei as duas pernas e fiquei um bom tempo sem poder trabalhar, minha esposa não trabalhava fora e precisou sair para trabalhar, uma vez que eu não podia trabalhar, eu era músico. Com o passar do tempo isso foi me incomodando, não poder trabalhar. Minha esposa saia todos os dias sempre bem arrumada e chegava tarde da noite, isso foi despertado o ciúme, passei a brigar com ela, a maltratar até que separamos, foi aí que resolvi procurar o Terreiro na esperança de fazer com que ela voltasse pra mim. Depois de alguns dias ela voltou a me procurar, vivemos mais algum tempo juntos mais acabamos separando. Com ela tive dois filhos. Depois casei com uma outra companheira. (Informação verbal) ${ }^{4}$.

Em outra direção, o Senhor Manoel da Cruz, de 78 anos de idade, natural do estado de São Paulo e morador do Bairro Primavera desde 1979, reforça os silêncios reveladores. O medo transparece nas reticências, pois insere a figura de Mãe Isabel dentro do imaginário criado em torno dos pais e mães de Terreiros, que já ocuparam a região:

[...] conheci, eu nunca frequentei a casa dela, mas conhecia de vista, fui uma vez em frente ao portão porque eu tive zipele [erisipela] aí um

\footnotetext{
${ }^{4}$ Informações fornecidas pelo Senhor José Santana de Aguiar. Entrevista realizada em 07/09/2019, Bairro Primavera, Ji-Paraná-RO.
} 
vizinho meu me levou lá, mas nem entrei lá pra dentro do portão. (Informação Verbal) $)^{5}$.

O racismo velado e o medo de terem suas imagens relacionadas à Umbanda, levaram muitas pessoas a afirmarem que embora tenham recorrido à religião pela necessidade, não estabeleceram com ela nenhuma ligação permanente. Não obstante, Jorge Luiz Barbosa, de 47 anos, conhecido como "Jorjão", apresenta uma leitura completamente diferente. Proprietário de um bar e praticante da religião afro-brasileira desde que nascera, é morador do bairro Primavera desde o ano de 1972. Ali conheceu as dinâmicas de Terreiro antes mesmo da chegada de Dona Maria Isabel, com quem construiu uma relação de proximidade. Através da narrativa de Jorjão, outra interpretação permite um contraponto aos silêncios, devolvendo à memória de Mãe Isabel o seu papel de direito na comunidade e dentro da Umbanda:

[...] frequentava, eu convivi com esse pessoal: Edvaldo, Camilo, Fio, mas eu não lembro, mas convivi dentro do Terreiro. Festa? Todo ano tinha festa. Era muita festa, olha fazíamos festa pra Cosme, Boiadeiro, lemanjá, Preto Velho, para várias entidades a gente fazia festa, antigamente tinha assim dia 13 as pessoas parava para ir nesses lugares, referindo aos Terreiros, hoje isso acabou, porque hoje em dia gera dinheiro, ou seja, gasto, antigamente era mais fácil, hoje é mais difícil, pra fazer uma festa hoje. Antigamente a pessoa dava um boi, um cabrito, dava um porquinho, levavam galinha pra gente assar, hoje ninguém quer fazer isso mais, tem que tirar do bolso pra fazer essas coisas, antigamente não as pessoas curtiam muito isso aí. Eu cansei de

\footnotetext{
${ }^{5}$ Informações fornecidas pelo Senhor Manoel da Cruz. Entrevista realizada em 07/09/2019, Bairro Primavera, Ji-Paraná-RO.
} 
ir em festa que diziam tem bois ganho, festa tal dia tem um boi ganho, as pessoas eram muito ligadas aos Terreiros hoje não. (Informação Verbal) ${ }^{6}$.

Através de Jorjão, a imagem pública de Dona Maria Isabel, a "Mãe Isabel" do Terreiro de Umbanda, se redimensiona:

[...] ela é muito amada aqui dentro do bairro, dentro do bairro Primavera a Dona Isabel era muito amada, até hoje as pessoas falam muito bem dela nunca desconsiderou ela, era uma senhora muito respeitada e amada aqui dentro. (Informação Verbal) ${ }^{7}$.

A tradição da festa e do festar que, inerentes à dramaturgia do sagrado umbandístico, também cumprem a função social de amenizar o sofrimento da pobreza e da fome, também aparecem na memória de Rosineia Aparecida de Lima, a "Rosi", nascida em 1972, na Cidade de Umuarama no estado do Paraná. Filha de Santo, passou a fazer parte da vivência do Terreiro a partir de 2010 e, em 2019, nos disse: “Lá a gente fazia as comemorações de Cosme Damião, Preto Velho, lá era um lugar simples, ela era simples". (Informação Verbal) ${ }^{8}$. Logo, as narrativas dão conta de que o Terreiro de Mãe Isabel se consolidou à luz desta tradição, pois preservava o calendário

\footnotetext{
${ }^{6}$ Informações fornecidas pelo Senhor Jorge Luiz Barbosa. Entrevista realizada em 07/09/2019, Bairro Primavera, Ji-Paraná-RO.

${ }^{7}$ Informações fornecidas pelo Senhor Jorge Luiz Barbosa. Entrevista realizada em 07/09/2019, Bairro Primavera, Ji-Paraná-RO.

8 Informações fornecidas por Rosineia Aparecida de Lima. Entrevista realizada em 07/09/2019, Bairro Primavera, Ji-Paraná-RO.
} 
religioso mantendo as festas em oferenda aos Pretos Velhos, lemanjá, Boiadeiros, Caboclos e demais entidades.

A iconografia a seguir revela que o Terreiro possuía uma relação intrigante com o espaço público e que, por si só, desafia os silêncios e interditos. Como se pode observar, o muro não estabelecia o limite do Templo, resguardando das vistas o exercício mesmo do sagrado. Pelo contrário, ressalta a extensão das práticas do Terreiro, por ser o suporte da estrutura que compõe a simbologia da Casa. Desta forma, o espaço público também se torna sagrado, integrando elementos inerentes às religiões de matriz africana.

FOTOGRAFIA 1: Paisagem diurna do Terreiro de Umbanda da dona Maria Isabel no Bairro Primavera na cidade de Ji-Paraná, 2018.

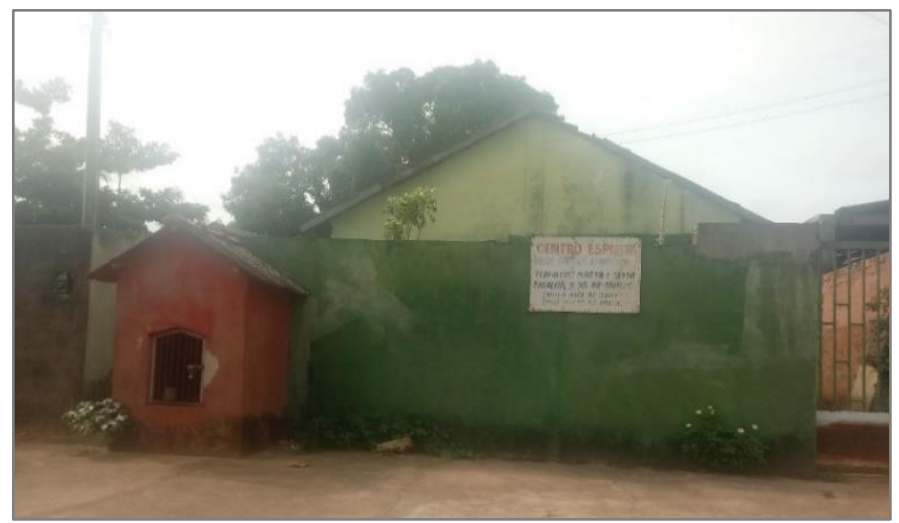

FONTE: Acervo do pesquisador Rodiney Nunes de Oliveira.

A casinha em vermelho, projetada para fora do muro e erguida rente à calçada, agrega em seu interior diversas imagens da religiosidade afro-brasileira. Trata-se, dentro deste 
sagrado, de uma "casa de forças", responsável por volatizar ou redimensionar as energias ou "larvas astrais".

FOTOGRAFIA 2: Paisagem noturna do Terreiro de Umbanda da dona Maria Isabel no Bairro Primavera na cidade de Ji-Paraná, 2018.

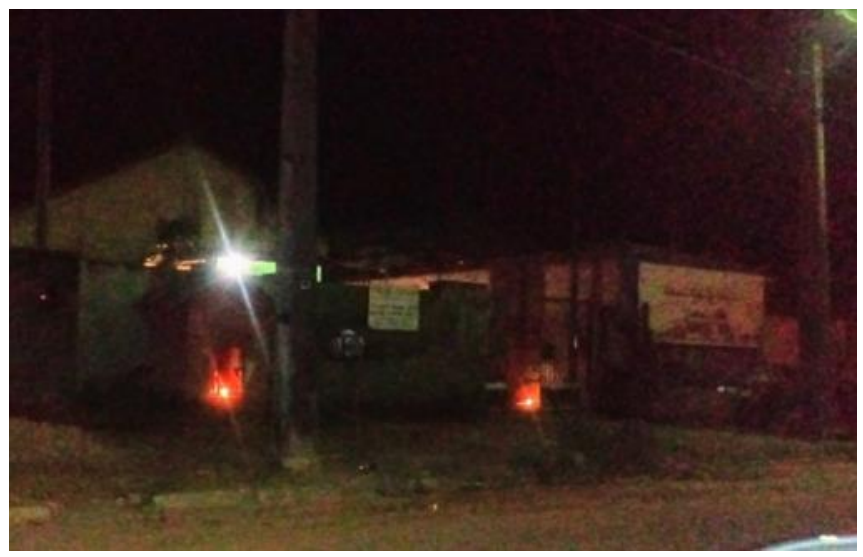

FONTE: Acervo do pesquisador Rodiney Nunes de Oliveira.

Comumente, estruturas deste tipo são mantidas na parte interior do terreno, ainda que nas proximidades do portão de acesso às casas de Umbanda, resguardando o espaço religioso em seus intramuros. No caso do Terreiro de Mãe Isabel, erguido na década de 1980, tanto transeuntes quanto moradores do bairro Primavera, tinham pleno conhecimento da casa de Umbanda ali edificada.

A Fotografia 2 revela, ainda, que inclusive à noite a referência ao sagrado umbandístico, ficava clara. Atravessando os limites do espaço privado da residência, a Casa de Forças e o "Cruzeiro das almas" eram iluminados por velas, ficando 
perfeitamente visíveis, bem como a placa que indicava o local como "Centro Espírita", aberto ao público.

Em se tratando da nomenclatura de "Centro Espírita", é importante salientar que muitos Terreiros de Umbanda, Brasil afora, assumiram esta nomeação a fim de fugir da perseguição às religiões de matriz africana. A ideia que subjaz nestas referências é correlativa ao espiritismo kardecista, tido no imaginário popular como religião que trata diretamente com "espíritos de luz" o que, no mesmo imaginário, afastaria o "Centro Espírita" da conotação pejorativa de "magia negativa" ou "macumba".

A despeito da nomenclatura, o espaço do sagrado registrado pelas Fotografias 1 e 2, estava publicamente explicitado. A configuração simbólica do local acentuava-se à noite, em especial nos dias em que os trabalhos eram realizados, quando reluziam as velas, acesas na parte externa, diante da Casa de Forças e do Cruzeiro das Almas. A iluminação bruxuleante, fortemente simbólica, não deixava dúvidas sobre a religiosidade ali consagrada. Da mesma forma, reforçavam a condição de Dona Maria Isabel como Mãe de Terreiro.

Conforme nos informou seu filho Edson, em São Paulo e no Paraná ela exerceu apenas os seus dons de "benzedeira". Foi, porém, no Terreiro do "Pai Lírio" que começou a trabalhar com entidades e "cruzar as linhas", pois as práticas da Umbanda realizadas em alguns Terreiros, além da Gira também 
desenvolviam trabalhos por encomenda, em atendimento à solicitação do consulente, servindo de referência para vários médiuns ${ }^{9}$. A partir das ponderações de "Edinho", nos foi possível demarcar o tempo e o espaço em que se situou o fazer religioso de Mãe Isabel, no âmbito da religiosidade afro-brasileira e, ao mesmo tempo, o seu vivenciar a Umbanda, no estado de Rondônia.

O encontro de Dona Maria Isabel com a Umbanda, se deu na década de 1970 através da relação construída no Terreiro do "Pai Lírio". Também localizado no bairro Primavera, este Terreiro era um reduto de negros, homens e mulheres migrantes, que se deslocaram de outras regiões do país. Neste sentido, Rondônia foi um lugar de mediação, mas também um divisor de águas para a prática religiosa de Dona Maria Isabel.

Sua vivência no estado funcionou como um cadinho, no qual se misturaram à Umbanda, as experiências trazidas, desde a infância, da religiosidade popular, das práticas de cura, benzeções e consultas por meio de mesa branca, vivenciadas em outras localidades. Ainda segundo Edinho, o aprendizado da ritualística dos Terreiros, só ocorreu quando a família já havia se estabelecido em Rondônia:

Ela começou a trabalhar no Terreiro depois que chegou em Rondônia, lá fora ela tinha uma mesa branca em casa com velas brancas e quando

\footnotetext{
9 Informações fornecidas pelo Senhor Edson filho da Dona Maria Isabel. Entrevista realizada em 07/09/2019, Bairro Primavera, Ji-Paraná-RO.
} 
as pessoas iam ela recebia as entidades e fazia os trabalhos, quando chegou aqui começou a conhecer as pessoas que trabalhava dessa forma foi que ela começou. (Informação verbal) $)^{10}$.

A chegada em Rondônia, demarca, portanto, o contato efetivo de Dona Maria Isabel com a Umbanda, ao passo que a sua imersão definitiva nesta religiosidade se deu através dos laços construídos no bairro Primavera. Todavia, como já se antevê na narrativa de Edinho, os dons espirituais de Dona Maria Isabel se manifestaram antes do seu encontro com a Umbanda. Em suas lembranças, ela mesma nos disse que suas primeiras experiências ocorreram aos 16 anos de idade. Elas vieram por meio de sonho:

Em seu dizer começou a desenvolver por sonho, começou na mesa branca e depois passou para a Umbanda, de acordo com os relatos dela um homem apareceu em sonho e apresentou como Dr. Eurico de Barros, que fazia operação de vesícula, todo de branco e disse que ela deveria comprar sete velas brancas, um lenço branco, sete pires e um litro de água e fosse na beira de um rio, pediu para forrar o chão e acender as sete velas e colocar os pires sobre o pano branco, esse espírito não permitiu que ela o visse, pediu para deixar tudo lá e fosse embora sem olhar para trás, deveria ser feito ao meio dia, em seus pensamento ela achava que se virasse para olhar iria vê-lo materializado mas também poderia ter suas consequências e assim ela fez (Informação verbal) ${ }^{11}$.

O sonho com o espírito do Doutor Eurico de Barros, aconteceu em Terra Rocha, no Paraná, quando Dona Maria

\footnotetext{
10 Informações fornecidas pelo Senhor Edson filho da dona Maria Isabel. Entrevista realizada em 07/09/2019, Bairro Primavera, Ji-Paraná-RO.

11 Informação narrada pela Dona Isabel e anotada pelo pesquisador em seu caderno de anotações. Trabalho de campo realizado em 07/06/2018.
} 
Isabel ainda estava na companhia de seus pais e onde, também, já havia aprendido a arte da benzeção. Também ali, em uma situação de enfermidade, vivenciou uma experiência sobrenatural juntamente com seus pais, guiados por seu mentor espiritual:

Ao anoitecer o espírito do Dr. Eurico de Barros desce na "coroa" dela e conversou com seus pais explicando que ela desde o ventre já tinha sido escolhida para trabalhar no mundo espiritual e que a partir daquele momento ela deveria se entregar ao trabalho e muitas coisas iriam mudar em sua vida e que iria fazer operação de vesícula. (Informação Verbal) ${ }^{12}$.

Este é o fio criado por Dona Maria Isabel ao estabelecer o diálogo do presente com o passado. A figura do mentor e da experiência mística na juventude, a vinculam à religiosidade de matriz africana como predestinação, ou seja: ocorre um chamado, ao qual ela responde, por ter sido escolhida para o ofício.

O encontro com a Umbanda se deu, assim, na sua maturidade, dentro de um entorno geográfico marcado pelo sagrado afro-brasileiro. A prática do Terreiro era uma realidade instituída, aceita e reconhecida no bairro Primavera, antes de sua chegada em Rondônia. Já naquela época, o bairro era objeto de olhares preconceituosos e de discriminação racial. Contudo, vicejaram nele diversos Terreiros, instigando uma

\footnotetext{
12 Informação narrada pela Dona Isabel e anotada pelo pesquisador em seu caderno de anotações. Trabalho de campo realizado em 07/06/2018.
} 
intensa movimentação religiosa, fruto do modo de vida dos seus moradores.

Neste cenário religioso, tornaram-se guardiões dos Terreiros no bairro Primavera: Pai Lírio, Camilo e Gedevaldo, sendo este último a sua principal referência ${ }^{13}$. A partir das lembranças do "Jorjão", que cresceu no bairro Primavera e era neto de Zelador de Terreiro, estas figuras fundamentais para a história do bairro e da Umbanda em Ji-Paraná, rompem os véus de silêncio, impostos pela memória dominante e se atualizam:

[...] mas eu fui criado nisso ai, meu velho, meu avô, que é o Lírio, eu acompanhei muito ele, aprendi muito com ele, aí veio o irmão, Pai de Santo que era o Camilo, mais pra frente conheci o Gedevaldo, que era o mais respeitado aqui dentro e Dona Isabel. Dona Isabel na verdade ela foi desenrolada, feita, no Terreiro do meu velho, do meu avô, ela passou a conhecer a entrar na Gira, realmente ela foi uma mulher de muita confiança no seguidor do espiritismo. (Informação Verbal) ${ }^{14}$.

Por outro lado, a existência sócio histórica de Dona Maria Isabel, no seu fazer-se como Mãe de Terreiro, se deu em um contexto de transição, quando os templos de matriz africana

\footnotetext{
${ }^{13}$ Pai Lírio, Camilo e Gedevaldo deslocaram-se para o estado de Rondônia na década de 1970. Foram os percussores da prática religiosa de matriz africana na cidade de Ji-Paraná, especialmente no Bairro Primavera, local em que tinham os seus Terreiros estabelecidos. Sua importância se dava pela representatividade por eles alcançadas, que resultou na aceitação e no reconhecimento pelo trabalho que realizaram à luz da orientação dos orixás e das identidades dos Terreiros. Suas histórias até então desconhecidas ressoam nas lembranças de quem frequentava os Terreiros à época, e hoje os referendam com os "responsáveis" por avivar a Umbanda e o Candomblé em Ji-Paraná. Suas histórias nos permitem considerar que o Bairro Primavera já foi um grande celeiro das religiosidades afro-brasileiras, que ali ganharam vida e floresceram ao longo do fazer-se da comunidade. 14 Informações fornecidas pelo Senhor Jorge Luiz Barbosa. Entrevista realizada em 07/09/2019, Bairro Primavera, Ji-Paraná-RO.
} 
foram paulatinamente perdendo a hegemonia no bairro Primavera, diante do avanço das Igrejas Evangélicas. Neste sentido, o terreiro de Mãe Isabel, seu existir e seu persistir, tanto representou um fio de ligação com um passado vicejante, quanto um bastião de resistência. Conforme lembra o Senhor José Luiz Barbosa,

[...] Candomblé é o que mais tinha, aí o que que acontece, passou assim mais ou menos uns 6 a 8 anos o pessoal começou a aproximar das Igrejas Evangélica, crente, aí alguns foram afastando do Candomblé, para irem para o evangélico e aqueles antigos, os cabeças, com o tempo foram morrendo e o povo foi desacreditando de tanto as pessoas falarem mal do espiritismo, porque quem não conhece essa seita da Umbanda, do Candomblé, da Quimbanda, eles falam muito sem saber o que é isso aí. (Informação verbal) $)^{15}$.

A interpretação do Senhor José Luiz se dá na conexão do seu presente (2019) com o seu passado (meados da década de 1970), momento em que sua infância e adolescência ali se enraízam. Por sua vez, situa as próprias lembranças em diferentes temporalidades, permitindo ao pesquisador configurar o tempo da memória em duas dimensões: a primeira se inscreve no momento em que práticas religiosas de matriz africana, a exemplo do Candomblé, agregavam uma grande concentração de Terreiros. O bairro Primavera apresentou esta configuração até meados de 2010. A segunda dimensão, se inscreve nas transformações a que foram submetidas o bairro e a justificativa

\footnotetext{
${ }^{15}$ Informações fornecidas pelo Senhor Jorge Luiz Barbosa. Entrevista realizada em 07/09/2019, Bairro Primavera, Ji-Paraná-RO.
} 
que faz das religiões de matriz africana não ocuparem a centralidade das práticas religiosas.

Suas explicações se balizam, por um lado, na presença da religião evangélica e a significação que a ela os moradores passaram atribuir; além disso, demarca como ponto importante desta transição, a morte dos principais zeladores dos Terreiros, tendo início o processo de descaracterização.

O cenário apresentado pelo Senhor José Luiz foi o pano de fundo para a experiência de vida e de fé de Dona Maria Isabel, no bairro Primavera. Afinal, ela permaneceu ali por quase quatro décadas, tornando-se uma representante das pessoas vinculadas às religiões de matriz africana. Não obstante, as representações do bairro entre as décadas de 1970 e 1980, dão conta de um lugar pequeno, no qual a rua assumia um importante papel social, pois era o espaço de lazer para as crianças e principal referência para o encontro dos adultos e a construção das sociabilidades.

Como vimos, foi neste cenário que Dona Maria Isabel se vinculou à Umbanda. A vivência com o "Pai Lírio" a conduziu à abertura de um novo Terreiro, o qual se tornaria um elo com o passado. O Terreiro de Mãe Isabel, erigido em novo momento histórico, preservou a memória cultural e as experiências de vida de negros e negras que também inscreviam suas histórias no estado de Rondônia, inserindo na nova realidade as práticas culturais apreendidas nas regiões em que antes viviam. 
A presença de Dona Maria Isabel como zeladora de um Terreiro de Umbanda no bairro Primavera, se deu no intervalo temporal de aproximadamente 40 anos, se tomarmos como referência a narrativa de seu filho:

Em 1977 Dona Maria Isabel construiu um quarto no fundo da casa e começou então atender no seu próprio Terreiro, antes disso ela era mãe pequena no Terreiro do "Pai Lírio". (Informação verbal) ${ }^{16}$.

Vale lembrar que seu fazer como umbandista foi anterior à abertura da referida casa, já que foi membro do Terreiro do "Pai Lírio". Com ele, Mãe Isabel aprendeu os segredos da religiosidade, pois atuou como Mãe Pequena, auxiliando-o na realização dos trabalhos da Casa. Por sua vez, o reconhecimento de sua prática e a abertura do seu próprio Terreiro, foram condicionados à avaliação pela Federação dos Umbandistas do estado de Rondônia, conforme revela sua narrativa: "Fui na Federação e precisei fazer um teste com os sete pontos, de todos os orixás, estudei a semana toda para fazer o teste para receber o certificado e passar a trabalhar"17.

Dona Maria Isabel iniciou seus trabalhos como zeladora de Terreiro em um espaço às margens da Rodovia Federal principal. Suas práticas religiosas consistiram em atividades consideradas "mesa branca", por meio de orações e consultas.

\footnotetext{
${ }^{16}$ Informações fornecidas pelo Senhor Edson filho de Dona Maria Isabel. Entrevista realizada em 07/09/2019, Bairro Primavera, Ji-Paraná-RO.

${ }^{17}$ Informação narrada por Dona Maria Isabel e anotada pelo pesquisador em seu caderno de anotações. Trabalho de campo realizado em 07/06/2018.
} 
Já a sua afirmação na prática da Umbanda se deu quando se tornou zeladora do "Terreirinho", erguido no fundo no quintal de sua residência. A Casa era denominada de "Terreirinho", pois sua estrutura simples não conseguia abrigar o quantitativo de pessoas que buscavam suas orientações espirituais.

A pequena acomodação e a infraestrutura precária conduziram à construção de um novo Terreiro, no mesmo terreno, agora situado na parte frontal da residência. De acordo com a memória de Edinho:

[...] O que lembro é que era muito movimentado, minha mãe era muito procurada, vinha pessoas de vários lugares para consultar com ela, até de Porto Velho vinha. Acredito que quando ela trabalhava no "Terreirinho", [mencionando seu primeiro Terreiro] era muito melhor do que esse que ela teve por último, quando ela vai pra lá começou a mudar, um chega e fala que tinha que ser assim outro fala outra coisa e as coisas foram mudando, não pra ruim mas mudou a forma de trabalho, aqui ela não usava bebida alcoólica, como ela usava nesse último. (Informação Verbal) ${ }^{18}$.

A vivacidade do Terreiro, rememorada por Edinho como um lugar "movimentado", é reafirmada pela narrativa de Mãe Rosi, que acompanhou Dona Maria Isabel até seus últimos dias:

[...] tinha várias pessoas né, não dá de lembrar de todos porque são muitas né. De todo jeito, rico, pobre, branco, negro, mendigo, esse povo que é usuário de drogas, sempre chegava para pedir uma comida, uma água, um café. Entendeu, ela não tinha as portas fechadas, a porta dela sempre estava aberta para acolher a todas as pessoas, muitas pessoas

\footnotetext{
${ }^{18}$ Informações fornecidas pelo Senhor Edson filho de Dona Maria Isabel. Entrevista realizada em 07/09/2019, Bairro Primavera, Ji-Paraná-RO.
} 
de outra crença, para ela não tinha distinção de crença, raça ou posição na sociedade. (Informação verbal) ${ }^{19}$.

Os narradores nos auxiliam a pensar o processo de aceitação e reconhecimento do exercício religioso de Mãe Isabel, na medida em que o transmutar do Terreiro é dimensionado no e sobre o tempo. Por conseguinte, as referidas alterações espaciais também incidiram sobre o desenvolvimento das práticas religiosas. É neste sentido que Edinho tenta descrever o transformar do Terreiro e sua ampliação espacial a partir da história do "Terreirinho", até sua configuração última, pois de acordo com o mesmo:

A ideia nasceu do povo que achou que estava muito pequeno, porque ela atendia em um espaço no fundo da casa. E através de mutirão foi construído, cada um ajudou da forma que podia, como telha, tijolo, cimento, areia..., eu sou pedreiro então eu dava a mão de obra. (Informação Verbal) ${ }^{20}$.

A ideia de mutirão apontado por Edinho também revela os laços de afeto e do estreitamento social que orientavam as ações dos sujeitos envolvidos com a Umbanda e com o Terreiro de Mãe Isabel. Percebe-se na prática, o reconhecimento da Umbanda como alento da própria experiência de vida. Entretanto, é preciso considerar que a ampliação do espaço redimensionou as práticas desenvolvidas no Terreiro,

\footnotetext{
${ }^{19}$ Informações fornecidas pela Senhora Rosineia Aparecida de Lima. Entrevista realizada em 10/09/2019, Bairro Primavera, Ji-Paraná-RO.

${ }^{20}$ Informações fornecidas pelo Senhor Edson, filho da dona Maria Isabel. Entrevista realizada em 07/09/2019, Bairro Primavera, Ji-Paraná-RO.
} 
modificando aspectos fundamentais da ritualística sagrada, que até então marcara a prática de Mãe Isabel.

Simbolicamente, o Terreirinho, consistia em um lugar mais simples, no qual ela dava os seus primeiros passos como zeladora. Paulatinamente, porém, o reconhecimento e a aceitação de Mãe Isabel se expandiram. Desde então, ela se transformou em referência no Bairro Primavera, digna de estima e de respeito:

[...] ela é muito amada aqui dentro do bairro, dentro do Bairro Primavera a Dona Isabel era muito amada, até hoje as pessoas falam muito bem dela nunca desconsiderou ela, era uma senhora muito respeitada e amada aqui dentro. (Informação verbal) ${ }^{21}$.

Elemento de ligação das memórias de experiências negras em Ji-Paraná, podemos situar Dona Maria Isabel em um momento de transição da geografia sagrada assumida pelo bairro. Novas experiências tornaram-se cotidianas para a prática da Umbanda e do Candomblé na cidade de Ji-Paraná. Os ataques e pressões sofridos pela reconfiguração evangélica, afloraram a intolerância, o racismo e o preconceito social, até então presentes, mas não declarados.

A forte presença evangélica, atuando como força contrária, empurrou os Terreiros para o interior da mata e fundos dos quintais, de modo que as poucas estruturas semelhantes ao Terreiro de Dona Maria Isabel, à frente e projetadas para o

\footnotetext{
${ }^{21}$ Informações fornecidas pelo Senhor Luiz Barbosa. Entrevista realizada em 07/09/2019, Bairro Primavera, Ji-Paraná-RO.
} 
espaço público, tenderam a desaparecer, não apenas do bairro Primavera, mas na cidade de Ji-Paraná ${ }^{22}$. Conforme revela a interpretação de Jorge, as relações entre as igrejas evangélicas e os Terreiros são tensas:

Relação dos Terreiros com a Igreja Evangélica nenhuma. Não tem porque os evangélicos condenam o Terreiro, o evangélico condena até a Igreja Católica você pode ver que até entre eles um não entende o outro se você vai Assembleia você vai ouvir uma conversa, na batista outra, na adventista outra, eles mesmo não se entendem os homens em questão de religião não se entende igual na política, se for discutir dá briga, é umas coisas que existe precisamos delas, mas se for discutir dá briga. Ela existe nos precisamos dela, não entendo (Informação verbal) ${ }^{23}$.

O fazer-se religioso, se redimensiona ao longo do tempo de tal forma que as memórias e os ensinamentos de Mãe Isabel ganham vida em outros espaços e momentos. É o caso de Mãe Rosi, uma de suas auxiliares no trabalho da Casa que, atendendo ao seu próprio chamado espiritual, abriu seu Terreiro, após o falecimento de Mãe Isabel. O Terreiro de Mãe Rosi foi erguido também no quintal de sua casa, em outra região da cidade. Todavia, as diversas imagens que estavam no Terreiro de sua mentora foram levadas para compor o altar, uma vez que tinha o aval de Mãe Isabel. Em respeito ao desejo de sua mãe, Edinho permitiu a retirada das imagens.

\footnotetext{
${ }^{22}$ Durante a pesquisa realizada não encontramos nenhum registro dos Terreiros de Umbanda e Candomblé nos arquivos da Prefeitura Municipal em Ji-Paraná.

${ }^{23}$ Informações fornecidas pelo Senhor Jorge Luiz Barbosa. Entrevista realizada em 07/09/2019, Bairro Primavera, Ji-Paraná-RO.
} 
Este processo de transferência de objetos sagrados, revela a clareza que Dona Maria Isabel possuía de sua missão religiosa. Ela percebia a importância de dar continuidade ao Terreiro, após a sua partida do mundo físico, pois outras Casas deixaram de realizar o trabalho espiritual com o falecimento de seus zeladores ou pela conversão de pais e mães de Santo às igrejas evangélicas. Neste sentido, sempre foi preocupação de Mãe Isabel, que a experiência aprendida não desaparecesse, depois de seu falecimento. É por esta lógica que devemos considerar a escolha de Mãe Rosi para sucedê-la com os segredos e os aprendizados do Terreiro.

Rosineia Aparecida de Lima, nasceu em Umuarama, no Paraná. Antes de seu contato com a Umbanda, frequentava a religião católica. Todavia, tal como Dona Maria Isabel, sua história é marcada pelo sofrimento e pela pobreza.

Antes de fazer parte do Terreiro de Mãe Isabel, Rosi já havia sido iniciada na Umbanda por uma senhora ligada aos Terreiros da Bahia. Segundo sua interpretação: "[...] É da Umbanda, porque eu gosto de todas, mas que foi escolhido foi esse, onde foi feito a cabeça”. Ainda de acordo com Mãe Rosi, o seu contato com a religiosidade de matriz africana se deu em função da sua mediunidade, com a qual não sabia lidar:

Então primeiramente, na verdade eu não queria, então saí pra longe pra trabalhar né, ai começou acontecer umas coisas, eu comecei a desmaiar mas eu ficava consciente e ouvia tudo que as pessoas falavam, era do nada, de repente eu desmaie pela terceira vez, a pessoa me segurou aí cuidou de mim mais a cozinheira, hora que eu 
voltei em si ele falou pra mim, "é minha filha, você tem um destino muito longo pela frente, você não vai para por aí não, o que você tem que fazer agora, é ir pra sua cidade chegando lá vai procurar uma mãe de santo, vai começar a se cuidar, porque você é a única da família que vai receber o cargo de cuidar tanto de sua família como de outras pessoas que irão aparecer " mas eu disse: eu não quero. Ele falou "tudo vai acontecer na hora e no momento certo". (Informação Verbal) ${ }^{24}$.

Na narrativa de Mãe Rosi, também se observa o caráter da "predestinação". Dentro da mesma lógica que marcou a trajetória espiritual de Mãe Isabel - de outras mulheres de fé, vistas neste livro -, ela estava predestinada a desenvolver sua mediunidade e assumir uma função na Umbanda. Deste modo, ao "aceitar o convite" apenas cumpria sua missão. Contudo, teve que enfrentar várias dificuldades no processo de aceitação:

Quando voltei pra Ji-Paraná, não estava sentindo muito bem, fiquei internada no hospital uma semana sem comer e sem beber, minha irmã que cuidava de mim, até que chegou um dia, numa sexta-feira, na hora da visita, eu estava deitada na cama perto da porta, no quarto tinha várias pessoas conversando, aí eu olhei para o rumo da porta aí eu falei assim pra minha irmã você não tá vendo não? Ela falou o que? Não tem nada na porta não falei tem sim, tem um homem moreno de chapéu, eu nunca vi esse homem, ele tá olhando pra mim, minha irmã falou: "[...] mas não veio ninguém aqui" eu disse: veio ele tava olhando pra mim. Foi aonde aconteceu; noutro dia recebi alta, pra quem não estava nem comendo e nem bebendo, foi um milagre, aí me trouxeram pra casa, ai minha mãe falou assim: "você não vai ficar assim, vou levar você em uma senhora que tem ali em cima dizem que ela é muito boa, eu confio em Deus e confio nela" que era a finada Tereza que tinha um Terreiro na T23, aí minha mãe me levou lá e ela cuidou de mim com muito carinho. [...] Ela disse: seu dom vem de berço, aí eu perguntei o que é dom, ela disse "você tem o dom dos orixás, você pode benzer, fazer as

\footnotetext{
${ }^{24}$ Informações fornecidas pela Senhora Rosineia Aparecida de Lima. Entrevista realizada em 10/09/2019, Bairro Primavera, Ji-Paraná-RO.
} 
limpezas, você pode fazer muitas coisas boas para ajudar quem precisa". (Informação Verbal) ${ }^{25}$.

Além de revelar seu processo de iniciação, Mãe Rosi nos aponta a presença de outro Terreiro no bairro Primavera, região em que se localizava o Terreiro de Mãe Isabel. Mas, sobretudo, evidencia o papel desempenhado pela Umbanda, como uma referência para o socorro das pessoas carentes, que se deslocavam aos Terreiros em busca de cuidados.

O encontro com Dona Tereza, do Terreiro na T23, reforçou seu chamado. Após a cura, Rosineia ficou distante quase um ano e meio do processo. Entretanto, seu caminho estava marcado e a busca por trabalho, no estado do Mato Grosso, a conduziu novamente ao universo da religiosidade de matriz africana, conforme nos contou:

Viemos embora, eu falei pra minha mãe que eu não queria isso pra mim, aí a minha mãe me disse que eu teria que seguir o meu destino, não porque você quer, foram eles que te escolheram, aí eu disse vamos ver, vou pensar. Aí passou mais ou menos um ano e começou a dar os desmaio novamente, aí eu sai daqui e fui pra Coniza, no Mato Grosso, em busca de trabalho. Chegando lá não tinha onde ficar, não tinha nem apartamento pra alugar. Aí conheci uma senhora lá, uma baiana; foi lá que começou tudo, ela começou a cuidar de mim, fez minha apreparação que não foi nada fácil, fiquei lá uns 8 meses; aí ela disse "[...] agora você precisa voltar pra sua casa, pois lá estão seus filhos, tua família e lá você vai encontrar um novo lugar para trabalhar". Chegando aqui procurei uma amiga e ela me disse que conhecia uma pessoa muito boa, muita gente conhece ela, se chama Isabel; eu disse

\footnotetext{
${ }^{25}$ Informações fornecidas pela Senhora Rosineia Aparecida de Lima. Entrevista realizada em 10/09/2019, Bairro Primavera, Ji-Paraná-RO.
} 
assim: onde ela mora? Aí ela me falou onde era, falei então tá, vou fazer uma visita. (Informação Verbal) ${ }^{26}$.

O retorno de Rosi para Rondônia, se deu em função da sua família e, acima de tudo, pela direção da sua mãe de Santo, de que deveria buscar um Terreiro para fazer parte. É possível perceber, através da narrativa, que mesmo tendo se iniciado e feito "a cabeça no Santo" na cidade de Colniza no estado do Mato Grosso, sua imersão na Umbanda ocorreu no Terreiro de Mãe Isabel.

[...] Aí me trocou e foi lá. Fui toda de branco, porque eu sempre gostei do branco, nossa minha roupa era toda branco, tudo que eu ia fazer era branco, cheguei lá ela me atendeu muito bem, tinha um banco no lado de fora, sentei e comecei a perguntar como era o procedimento dela com os filhos de santo que chegavam, o que tinha que fazer, aí ela foi me explicando e foi onde ela me convidou pra ficar no Terreiro com ela; aí eu não podia mais voltar atrás, eu aceitei e continuei com ela. Lá aprendi muita coisa, foi uma pessoa muito especial, me deu muito conselho, me ensinou o que era certo e errado, foi continuando. (Informação Verbal) ${ }^{27}$.

O convívio de Rosi no novo Terreiro teve início em 2010 e perdurou até o falecimento de Mãe Isabel. A sua convivência e o compromisso com o Terreiro, já que participava ativamente da Casa e auxiliava Mãe Isabel no desenvolvimento dos trabalhos, possibilitou uma relação estreita de amizade e o

\footnotetext{
${ }^{26}$ Informações fornecidas pela Senhora Rosineia Aparecida de Lima. Entrevista realizada em 10/09/2019, Bairro Primavera, Ji-Paraná-RO.

${ }^{27}$ Informações fornecidas pela Senhora Rosineia Aparecida de Lima. Entrevista realizada em 10/09/2019, Bairro Primavera, Ji-Paraná-RO.
} 
convite para assumir a condução do Terreiro, após o falecimento da zeladora:

Eu me lembro como se fosse hoje, pouco antes dela, ela já estava doente, aí quem assumiu tudo para preparar as festas, a responsabilidade era minha, porque ela já não aguentava mais caminhar, assim para fazer as correrias né, aí nós conversando lá, foi até no último trabalho que a gente fez, que foi a festa dos Pretos Velhos, ela falou assim: "[...] é minha filha você cuida direito porque na próxima festa eu já não vou mais estar aqui”. Eu falei que é isso madrinha, não fala isso, a senhora vai estar com nós sim, ela disse: "[...] não, mas se você quiser a responsabilidade e prometer pra mim que vai fazer as festas, vai fazer tudo direitinho, porque eu já estou velhinha, já não estou dando conta mais, aí eu abençoo você para você dar continuidade. Aí eu falei, se for da vontade de Deus, da vontade da senhora que eu continue eu aceito. Foi difícil falar isso, mas eu aceitei, eu era muito apegada a ela. (Informação Verbal) ${ }^{28}$.

A escolha de Mãe Rosi, relaciona-se com a preservação da memória de Mãe Isabel, mas também com a sobrevivência das religiosidades de matriz africana em Ji-Paraná, face ao avanço evangélico. Por isso, o fazer-se das religiosidades de matriz africana impõe uma reconfiguração constante das ações de resistência. Os templos são mantidos vivos pela continuidade das práticas, num movimento dialético permanente, de configuração e reconfiguração diante das pressões sociais.

A experiência de Dona Maria Isabel representa outras tantas trajetórias individuais, que buscaram na Umbanda meios para fugirem da fome e da pobreza, para sobreviverem às

\footnotetext{
${ }^{28}$ Informações fornecidas pelo Senhora Rosineia Aparecida de Lima. Entrevista realizada em 10/09/2019, Bairro Primavera, Ji-Paraná-RO.
} 
margens de uma sociedade marcada pela desigualdade social. São experiências marcadas pelo desencontro e a marginalização, nos mais diversos espaços sociais, mas que se encontraram na religiosidade e fizeram da fé a razão para sobreviver. Conforme esclarece Souza:

Trata-se de uma temática não aceita socialmente e que dimensionada pelo âmbito familiar ancorado nas religiões (católicas ou evangélicas) que conferem sentido ao viver dos mesmos (as) como práticas que orientam atos, conduz a tentativa de silenciamento com o propósito de evitar estigmatização e constrangimento, elucidando o medo e o tratamento inadequado para as referidas questões. (SOUZA, 2019, p. 19).

Rondônia é o estado da Federação que possui o maior percentual de sujeitos autodeclarados evangélicos: 33,8\%, conforme o Censo de 2010 do IBGE. Ainda segundo o Censo, os católicos são maioria, com 47,6\%. Em percentual mínimo, encontram-se os "espíritas" com 06\%, enquanto os praticantes de religiões afro-brasileiras são um vácuo silencioso no Censo: $0,0 \%$ das autodeclarações.

Ora, toda a discussão que já empreendemos até aqui, "desdiz" a informação presente no mapeamento do IBGE. Os percentuais sugerem uma ocultação da prática religiosa de matriz afro, submetida a constantes ataques e perseguições. É o que observa Jorge, um dos nossos entrevistados:

[...] isso aí eu falo pra você, porque você sabe o que é o Terreiro; na verdade pra quem abre o Terreiro já é marginalizado, entendeu, pra quem não conhece diz que é coisa do capeta, do cão, é isso é aquilo, tem muitas pessoas que criticam, na verdade; mas, no fundo acabam 
indo lá, mas é um direito deles, em qualquer religião que você for você vai ouvir uma falando mal da outra é igual a política. Mas se for pensar certinho, ninguém é o certo; nós não sabemos qual é a verdade. Se todos aqui nessa terra fosse certo o Pai lá [referindo-se a uma passagem bíblica], quem não tem pecado atire a primeira pedra, então, todos nós não sabemos qual é a verdade. (Informação verbal) ${ }^{29}$.

A despeito dos números apresentados pelo IBGE, o estado de Rondônia repete um panorama que é comum no restante do Brasil: uma diversidade de minorias, que se espraiam pelo tecido social das cidades, marcadas por uma acentuada desigualdade social. Neste cenário, a religiosidade popular, em todas as suas expressões, se constitui como uma válvula de escape para as pessoas que, sem amparo, se refugiam na fé em busca de socorro. Esta é, portanto, a mesma configuração sócio-histórica que forçou Dona Maria Isabel a criar meios e alternativas para garantir a sua sobrevivência e, ainda, oferecer lenitivo àqueles que a procuravam:

[...] Depois que deixei de trabalhar fora, passei a dedicar exclusivamente ao Terreiro, não sou aposentada recebo um benefício é com ele e a ajudas de pessoas quem vem aqui inclusive você eu consigo viver. Não atendo as pessoas pelo dinheiro, se elas têm condição paga, atendo, mas senão atendo do mesmo jeito, tem vez que tiro do meu para comprar os materiais para o trabalho. O Paulo, meu esposo, também me ajuda. O Centro já deu dinheiro, hoje não tem muitas gentes trabalhando na parte espiritual e hoje as pessoas gostam mais de fazer a maldade eu não faço isso, não gosto de fazer maldade

\footnotetext{
${ }^{29}$ Informações fornecidas pelo Senhor Jorge Luiz Barbosa. Entrevista realizada em 07/09/2019, Bairro Primavera, Ji-Paraná-RO.
} 
para ninguém. Não tem dinheiro que me compra para fazer maldade para alguém. (Informação verbal) ${ }^{30}$.

Dos pobres e miseráveis que chegaram em Rondônia e encontraram amparo no Terreiro de Mãe Isabel, destacamos a narrativa a seguir:

Morava em Cascavel perto de Guaíra [Paraná], a gente sofreu muito, viemos de pau de arara passamos 15 dias para chegar aqui. Quando chegamos aqui fomos morar na T10 e depois compramos essa casa aqui no Primavera. Trabalhávamos sempre em roça. Desde a idade de 8 anos eu benzia as pessoas. [...] sim era uma pessoa muito boa [Dona Maria Isabel], quando chegamos aqui no bairro, ela ajudou a matar a fome dos meus meninos, ela sempre procurava fazer o bem, eu não era de ir na casa dela e nem ela aqui, mas quando ela ia na missa, que passava por aqui, sempre conversávamos. (Informação verbal) ${ }^{31}$.

$\mathrm{O}$ acolhimento e a solidariedade, exercidos em meio ao trânsito religioso, oportunizaram o encontro de diversos registros culturais, ao colocar em contato sujeitos vindos dos mais diversos cantos do país. As ações de Dona Maria Isabel, como sujeito social e figura religiosa proeminente na sua comunidade, são expressivas deste processo. Já no final da sua jornada neste plano, considerou- se feliz:

Hoje não trabalho fora, até mesmo porque não aguento, a idade tem cobrado a minha juventude [disse em um tom de risada] [...] hoje trabalho em casa atendendo as pessoas, meu esposo, Paulo Pereira, trabalha aqui no fundo de casa consertando televisão, ventilador, máquina de lavar roupa, mas também é doente da coluna. Sou feliz com

\footnotetext{
${ }^{30}$ Informação narrada pela Dona Isabel e anotada pelo pesquisador em seu caderno de anotações. Trabalho de campo realizado em 07/06/2018.

${ }^{31}$ Informação narrada pela Dona Isabel e anotada pelo pesquisador em seu caderno de anotações. Trabalho de campo realizado em 07/06/2018.
} 
o que faço, não faço por dinheiro, se a pessoa que vem aqui buscar atendimento, se tem dinheiro eu faço mas se não tiver faço do mesmo jeito, precisamos ajudar uns aos outros, recebo ajudas das pessoas quem vem no meu Terreiro pedir ajuda. Não sou aposentada, sou encostada, recebo $\mathrm{R} \$ 900,00$ [novecentos reais] por mês, dessa forma é que sobrevivo e lógico com ajuda das pessoas e de você, que os Orixás permitiu nossos caminhos se encontrarem. (Informação

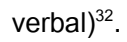

É possível afirmar que o espaço ocupado por Dona Maria Isabel e o papel social que desempenhou, foram fundamentais na história social do bairro Primavera. Não apenas a sua prática religiosa, mas também os serviços prestados à uma população carente, fizeram de Mãe Isabel um elemento aglutinador de sujeitos e culturas. Em um bairro marginalizado, sem infraestrutura, insalubre, povoado por negros e migrantes, Mãe Isabel e seu Terreiro ofereceram recursos materiais e espirituais para o enfrentamento da miséria e do abandono do Estado.

Sua trajetória pessoal anelou-se, de forma visceral, à trajetória histórica dos Terreiros de Umbanda em Ji-Paraná. Ali construiu uma nova etapa do seu existir, afirmando que "[...] o dia que não trabalha fica até doente". Em seus últimos anos, o espaço do Terreiro ao qual dedicou a vida, tornou-se, também, o local em que escolheu viver a maior parte do tempo que ainda

\footnotetext{
${ }^{32}$ Informação narrada por Dona Maria Isabel e anotada pelo pesquisador em seu caderno de anotações. Trabalho de campo realizado em 07/06/2018.
} 
Ihe restava: sentada em uma cadeira perto do altar. Enquanto pode, atendeu quem Ihe procurou, da forma que conseguiu:

[Em relação a manutenção do Terreiro ela afirma que antes as pessoas ajudavam, hoje muitos vão e nem uma vela leva, mas que ainda existe alguns que a ajuda]. Até mesmo para fazer os trabalhos muitos nem levam a vela e mesmo assim eu faço porque não faço pelo dinheiro, mas porque Deus me deu esse dom ${ }^{33}$.

Dona Maria Isabel Pereira dos Santos, faleceu na cidade de Porto Velho no dia 16 de junho de 2019 e foi sepultada na cidade de Ji-Paraná. Seu Terreiro foi transferido para outro, que está em processo de construção, sob a responsabilidade da lalorixá Rosi. Entretanto, uma vez situada em seu fazer social e histórico, Dona Maria Isabel rompe os liames do tempo e atravessa o portal entre mundos.

Como sujeito, vivenciou episódios repetidos de lutas pela sobrevivência, valendo-se de táticas, astúcias e trampolinagens para enfrentar as agruras que lhe reservaram o destino de mulher pobre, negra, trabalhadora e analfabeta. Sob a luz da religiosidade afro-brasileira, aprendeu a lidar e a conferir sentido à ausência de bens materiais, tornando-se protagonista da própria história e figura central da história da sua comunidade. Em meio às contradições inerentes ao seu tempo e lugar, foi autônoma e autora, encontrando possibilidades de

\footnotetext{
${ }^{33}$ Informação narrada por Dona Maria Isabel e anotada pelo pesquisador em seu caderno de anotações. Trabalho de campo realizado em 07/06/2018.
} 
sobrevivência nas margens e brechas da sociedade, que não conseguiu silenciar a sua fé. Os tambores ainda ressoam! 


\section{Considerações Finais}

A Pedagogia do Terreiro é um fazer-se plural. Se dá no cotidiano das práticas de Umbanda, à luz das significações e ressignificações, dos sentidos e sensibilidades, inerentes aos sujeitos que nela aprendem e repassam o aprendizado, construindo-se e reconstituindo-se no e sobre o tempo. Não se trata de uma metodologia alicerçada em dogmas e preceitos cristalizados, fundantes de uma religião padronizada. Pelo contrário, se concretiza na intuição, na interpretação dos saberes herdados, emanando da experiência muito particular do sagrado e da prática a ele vinculada. Como todo conhecimento, aquele que se constitui no chão dos Terreiros se remodela, atendendo às exigências do tempo e das necessidades do devir.

Um olhar apressado, arrisca-se a afirmar que este processo de produção, manutenção e reelaboração do conhecimento sagrado, inerente ao fazer religioso das casas de Umbanda não possui método, o que exigiria uma normatização capaz de formalizar a prática e os ritos. Aliás, como assim entenderam muitos intelectuais que se dispuseram a interpretála. Entretanto, a Umbanda é uma prática viva, em constante movimento de criação e recriação. Esse fazer-se, que é por 
definição dialético, se articula diretamente às vivências dos seus atores, sujeitos sociais, localizados historicamente. Assim, a Umbanda e toda a pedagogia que Ihe informa o sagrado, não é una. É múltipla.

Os praticantes da Umbanda, que recebem 0 conhecimento e o reelaboraram à luz das suas próprias vivências, conduzem suas vidas ancoradas nesta religiosidade. Sujeitos plurais, lidam e se relacionam com o sagrado por diferentes lógicas, as quais Ihes asseguram a possibilidade de "religarem" as suas experiências ao patrimônio coletivo da religião.

Religião dinâmica e em constante movimento, ergue-se sobre uma pedagogia intuitiva, que se conecta no tempo e no espaço, através do trânsito geográfico, das trocas e transmissões entre os sujeitos. Desta forma, os Terreiros que se espraiam de norte a sul do Brasil, configuram-se como lugares de memória, nos quais os indivíduos são responsáveis pela manutenção da tradição, a preservação da oralidade e a materialização de suas práticas. Desta forma, seus zeladores assumem na diversidade e, não raro, nas adversidades, a missão de repassar um rico manancial de significações socioculturais, partilhando com a comunidade de fé inúmeros saberes e práticas.

Mesmo as Casas que, aparentemente, sobrevivem no isolamento, se recriam e se (re) fazem, alimentando-se no 
silêncio que Ihes foi imposto. O trânsito silencioso dos praticantes é também uma ação de resistência, pois a religiosidade (re) existe nas fímbrias dos interditos. A Umbanda se recria, se remodela, trazendo para suas práticas e rituais a brasilidade, a regionalidade, a África distante, os legados de civilizações antigas presentes nas roupagens dos Pretos Velhos, Baianos, Boiadeiros, Erês, Caboclos, Exus, Franciscanos, Indus. O solo sagrado do Terreiro funciona como um grande portal, capaz de dar passagem às mais diversas energias que compõem o astral. Nele se realiza a odisseia brasileira, cuja ancestralidade afro se mescla e se mistura a outros saberes, redefinindo e redimensionando o fazer religioso da Umbanda.

Para aqueles que praticam, a existência de um cânone é desnecessária. Mesmo as tentativas de normatização, empreendidas no começo do século $X X$, diluíram-se na experiência subjetiva dos Terreiros, na qual a conexão com o sagrado é oportunizada pelos cheiros, sabores, pela vibração das orações, da vela em combustão, dos arrepios da pele, da energia que vem do som dos atabaques e dos pontos cantados. Aos sujeitos imersos na experiência mística do Terreiro, o sagrado ressoa de fora para dentro e de dentro para fora, ressignificado de formas múltiplas, em cada um que ali se conecta com o sobrenatural.

Se não estivermos abertos para a compreensão desta 
subjetividade, não entenderemos a engenharia sensível que permite o religare entre os dois mundos: o espiritual e o material, o céu e a terra. Não seremos capazes, enfim, de perceber a construção de toda uma pedagogia dos sentidos que oportuniza a experimentação do sagrado.

Abordar as religiões de matriz africana, não é um exercício fácil. Campo complexo, sua construção em solo brasileiro exige um diálogo com a escravidão e o tráfico negreiro, as origens e os substratos culturais de milhares de seres humanos escravizados, o racismo e o preconceito, as lutas e as resistências. Não obstante, ao lançarmos o olhar para o interior das religiosidades, ou seja, para o coração mesmo das suas práticas, encontramos 0 que chamamos de pedagogia, educando nos Terreiros populações negras e marginalizadas do país.

Sem dúvida, o caráter transgressor do conhecimento, fluído e vivo, nos recorda de que as práticas de escolarização instituídas, conferem sentido aos processos educacionais, mas não podem ser compreendidos como se fossem a própria educação. Reduzir a educação a tais práticas é considerar a morte de outras culturas e de seu papel social, cultural e ideológico. Destarte, podemos considerar igualmente transgressor, o ato de educar parcelas da população negra à luz das pedagogias do Terreiro.

Dentro da sua própria lógica, esta pedagogia ocorre no 
silêncio e longe dos holofotes, sobretudo devido ao horror intolerante de outras religiosidades. Às margens, existindo na premência da vida e enquanto resistência, o aprendizado traçado no Terreiro enlaça narrativas e interpretações plurais, mas que de forma uníssona, devolve naquele lócus e naquela comunidade de fé, a cidadania negada aos oprimidos. Os ensinamentos permitem aos filhos e filhas do Terreiro, redimensionarem sua identidade, construindo uma nova, com a qual retraçam e rearticulam sua convivência social.

Em meio às transformações que alteram a geografia das cidades no Brasil, os Terreiros sobrevivem, mantendo vivas suas tradições e se reinventando, de modo a subverter os mecanismos para silenciá-los. Neste sentido, sua existência e sua resistência, inclusive através da "maquiagem" expressa pela nomenclatura de "Centros Espíritas", são práticas educativas em meio a intolerância. Como a religiosidade dos oprimidos, o conhecimento do sagrado aprendido nos Terreiros se transforma em arte e instrumento de sobrevivência. É, assim, na imersão deste aprendizado que, vivendo nas margens, os filhos e filhas de Santo forjam ferramentas na luta contra a exclusão e o anonimato.

A Pedagogia do Terreiro é, enfim, essa arte do subverter-se para sobreviver, cuja operacionalidade de lutas se faz no silêncio. O silêncio é a chave e a pedra de toque do povo negro. Vista desta forma, a existência no silêncio deixa de 
significar esconder-se, conformar-se, negar. Ao contrário, implica em vigilância, resiliência e a resistência contra a intolerância e a perseguição.

No exercício pedagógico do Terreiro, os filhos e as filhas de Santo aprendem que a transformação social é possível. Do mesmo modo que também é possível humanizar as relações, fomentar as práticas de socialização, criar vínculos entre os excluídos e, ainda, construir uma outra sociedade, mais justa e mais fraterna. 


\section{Referências}

BÂ, Amadou Hampâté. Amkoullel, o menino fula . São Paulo: Palas Athena e Casa das Áfricas, 2003.

BARROS, M. Memórias inventadas: a segunda infância. São Paulo: Planeta, 2006.

BASTIDE, Roger. Estudos afro-brasileiros. São Paulo: Perspectiva, 1973.

CHAUI, Marilena. Introdução. In: BOSI, Ecléa. Memória e sociedade: lembranças de velhos. São Paulo: T. A. Queiroz/USP, 1987. pp. 17-32.

DIEHL, Astor Antônio. Memória e identidade: perspectivas para a história. In: Cultura historiográfica: memória, identidade e representações. Bauru/SP: Edusc, 2002.

ELIADE, Mircea. O sagrado e o profano. Tradução de Rogério Fernandes. São Paulo: Martins Fontes, 1992.

FERREIRA, Lígia F. "Negritude", "negridade" e "negrícia": História e sentidos de três conceitos viajantes. Revista Via Atlântica, n. 9, junho, 2006, n.p. Disponivel em: http://www.revistas.usp.br/viaatlantica/ article/view/50048/54176.

GOFF, Jacques Le. Memória. In ROMANO, Ruggiero (Dir.). Enciclopédia Einaudi. V. 1: Memória - história. Lisboa: Imprensa Nacional, Casa da Moeda, 2001.

ISAIA, Artur Cesar. Espiritismo, República e Progresso no Brasil. In: HOMEM, Amadeu Carvalho; SILVA, Armando Malheiro da; ISAIA, Artur Cesar. (org.). Progresso e religião: a República no Brasil e em 
Portugal 1889- 1910. Coimbra / Uberlândia: Imprensa da Universidade de Coimbra / EDUFU, Uberlândia, 2007, v.1, p. 285-306.

ISAIA, Artur Cesar. Religião e Magia na obra dos intelectuais da umbanda. Projeto História, São Paulo, n.37, p. 195-214, dez. 2008.

LODY, Raul. O povo de santo: religião, história e cultura dos orixás, voduns, inquices e caboclos. São Paulo: Martins Fontes, 2006.

ORTIZ, Renato. A morte branca do feiticeiro negro: Umbanda e sociedade brasileira. São Paulo: Ed. Brasiliense, 1999.

PEIXOTO, Norberto. Umbanda Pé no Chão: um guia de estudos orientado pelo espírito Ramatís. Limeira: Editora do conhecimento, 2008.

PINHEIRO, André. de O. Revista Espiritual de Umbanda: Representações, mito fundador e diversidade do campo umbandista. In: Espiritismo \& religiões afro-brasileiras: história e ciências sociais. São Paulo: Ed. UNESP, 2012.

PINTO, Júlio Pimentel. Os muitos tempos da memória. In: Projeto História. São Paulo/PUC, n 17, 1998. pp. 203-211.

POLLAK, Michel. Memória e identidade social. Revista Estudos Históricos, Rio de Janeiro: Ed UFRJ, v. 5, n. 10, p. 200-212, 1992.

POLLAK, Michel. Memória e identidade social. Tradução de Monique Augras. Estudos Históricos, Rio de Janeiro, v. 5, n. 10, p. 200-212, 1992.

RICOEUR, Paul. A memória, a história, o esquecimento. Campinas: Editora da Unicamp, 2007.

ROSSI, Paolo. O passado, a memória, o esquecimento: seis ensaios da história das ideias. São Paulo: Edunesp, 2010.

RICOUER, P. Tempo e narrativa (Tomo I). São Paulo: Papirus, 1994. ROHDE, Bruno. Faria. Umbanda, uma Religião que não Nasceu: Breves Considerações sobre uma Tendência Dominante na 
Interpretação do Universo Umbandista. Revista de Estudos da Religião. São Paulo: PUC, 2009., p. 77-96.

SEIXAS, Jacy Alves de. Os tempos da memória: (des)continuidade e projeção. Uma reflexão (in)atual para a história? Projeto História, São Paulo, v. 24, p.49, 2002b.

SOUZA, Vanderson Almeida de. Homossexualidade, educação e trajetórias femininas: direitos, histórias, conflitos e vivências na escola Cândido Portinari em Rolim de Moura - Rondônia. 2019. 65 f. Monografia (Especialização Diversidade e Gênero na Escola) Fundação Universidade Federal de Rondônia, Rolim de Moura, RO, 2019. 


\section{Sobre os Autores}

\section{Cairo Mohamad Ibrahim Katrib}

Pós Doutor pelo Programa de Pós-Graduação em História da Universidade Estadual de Maringá-PR-UEM (2018). Professor Associado II da Faculdade de Educação, da Universidade Federal de Uberlândia-UFU. É coordenador do Núcleo de Estudos e Pesquisas NEPERE; do Núcleo de Estudos e Pesquisas em Educação das Relações Raciais; do Núcleo de Pesquisas em Cultura Popular e Produção de Vídeo documentário da UFU -DOCPOP; e, ainda, Coordenador de Extensão do Núcleo de Estudos Afro-BrasileirosNEAB-UFU.

\section{Tadeu Pereira dos Santos}

Pós-Doutor em História (2017-2018), pela Universidade Federal de Uberlândia e especialista em História Africana e Cultura Afro-brasileira (2011). Professor efetivo Fundação Universidade Federal de Rondônia UNIR, onde desenvolve o projeto O Estágio Supervisionado do Curso de Rolim de Moura: os dilemas e os desafios enfrentados pelos discentes na realização do estágio. É ainda, membro do Núcleo Docente Estruturante (NDE) da mesma instituição.

\section{Rodiney Nunes de Oliveira}

Professor do Estado de Rondônia (RO). Graduado em História e Filosofia. Especialista em Educação de Jovens e Adultos com ênfase na diversidade e inclusão social, pelo Instituto Federal de Educação Ciência e Tecnologia de Rondônia (2017). Atualmente desenvolve projeto de especialização com sobre o tema Gênero e Diversidade na Escola na UNIR - Universidade de Rondônia. 


\title{
Sobre o Ebook
}

\author{
Formato: Digital \\ Suporte: PDF \\ Capa: Duo color \\ Tipografia: Utsaah
}

\author{
Editora Culturatrix \\ - publicações acadêmicas - \\ www.culturatrix.com
}

Diagramado por Escrita \& Criação - Uberlândia, MG. 
A obra consiste em um construto intelectual empreendido por três autores. Ao longo do trabalho, abordam as experiências de mulheres negras que fizeram da religiosidade afro-brasileira o seu porto seguro, pois não se curvaram ao racismo, ao preconceito e à discriminação social tão presentes em seu cotidiano. Pelo contrário, mediante o acolhimento, a luta pela transformação social e, sobretudo, pela manutenção de uma tradição religiosa, fizeram e ainda fazem reluzir as matrizes de cultura africana que permeiam e integram o seu modo de vida. Este livro apresenta o resultado de investigações dadas em contextos espaço temporais distintos, em Minas Gerais e em Rondônia, procurando ampliar os horizontes reflexivos acerca do processo de constituição identitária do fazer-se mulher negra no Brasil. 